\title{
Review
}

\section{A review of rainfall interception modelling}

\author{
A. Muzylo ${ }^{\mathrm{a}, *}$, P. Llorens ${ }^{\text {a }}$, F. Valente ${ }^{\mathrm{b}}$, J.J. Keizer ${ }^{\mathrm{c}}$, F. Domingo ${ }^{\text {d,e }}$, J.H.C. Gash ${ }^{\text {f,g }}$ \\ ${ }^{a}$ Instituto de Diagnóstico Ambiental y Estudios del Agua (IDAEA), CSIC, Solé i Sabarís, s/n, 08028 Barcelona, Spain \\ b Centro de Estudos Florestais, Instituto Superior de Agronomia, Universidade Técnica de Lisboa, Tapada da Ajuda, 1349-017 Lisboa, Portugal

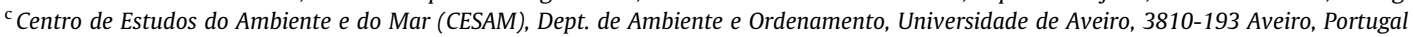 \\ ${ }^{\mathrm{d}}$ Estación Experimental de Zonas Áridas (EEZA), CSIC, General Segura, 1, 04001 Almería, Spain \\ e Universidad de Almería, Escuela Politécnica Superior, Dept. Biología Vegetal y Ecología, Almería 04120, Spain \\ ${ }^{\mathrm{f}}$ Centre for Ecology and Hydrology, Wallingford OX10 8BB, United Kingdom \\ ${ }^{\mathrm{g}} \mathrm{VU}$ University Amsterdam, Amsterdam $1081 \mathrm{HV}$, The Netherlands
}

\section{A R T I C L E I N F O}

\section{Article history:}

Received 19 November 2008

Received in revised form 29 January 2009

Accepted 23 February 2009

This manuscript was handled by $\mathrm{K}$. Georgakakos, Editor-in-Chief, with the assistance of Efrat Morin, Associate Editor

\section{Keywords:}

Interception

Rainfall partitioning

Modelling

Review

Evaporation

\begin{abstract}
S U M M A R Y
This paper is a review of physically-based rainfall interception modelling. Fifteen models were selected, representing distinct concepts of the interception process. Applications of these models to field data sets published before March 2008 are also analysed. We review the theoretical basis of the different models, and give an overview of the models' characteristics. The review is designed to help with the decision on which model to apply to a specific data set. The most commonly applied models were found to be the original and sparse Gash models (69 cases) and the original and sparse Rutter models (42 cases). The remaining 11 models have received much less attention, but the contribution of the Mulder model should also be acknowledged. The review reveals the need for more modelling of deciduous forest, for progressively more sparse forest and for forest in regions with intensive storms and the consequent high rainfall rates. The present review also highlights drawbacks of previous model applications. Failure to validate models, the few comparative studies, and lack of consideration given to uncertainties in measurements and parameters are the most outstanding drawbacks. Finally, the uncertainties in model input data are rarely taken into account in rainfall interception modelling.
\end{abstract}

(c) 2009 Elsevier B.V. All rights reserved.

\section{Contents}

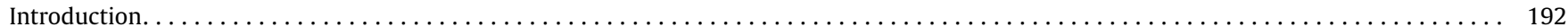

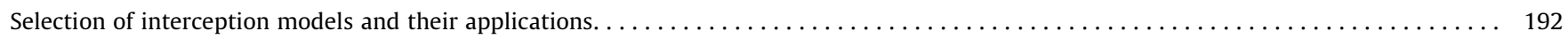

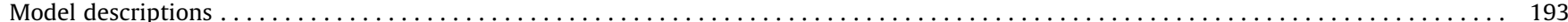

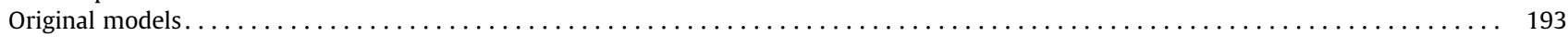

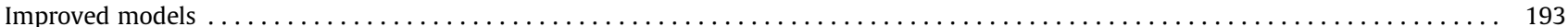

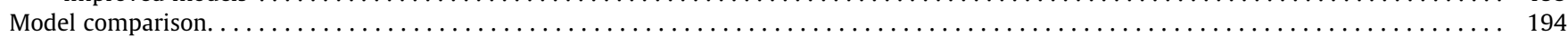

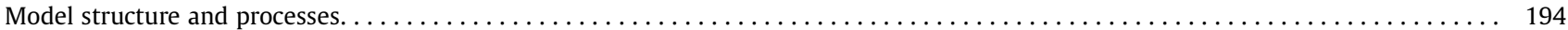

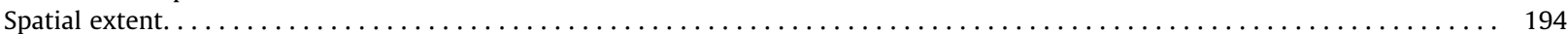

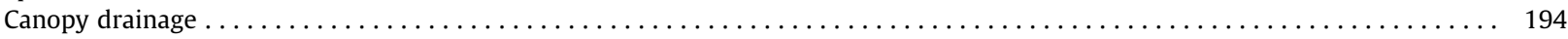

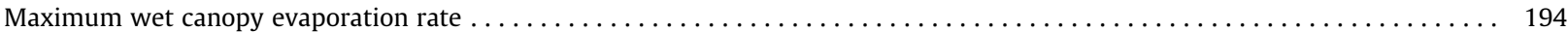

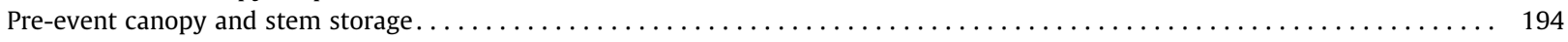

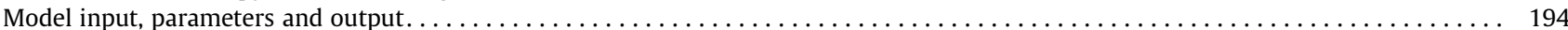

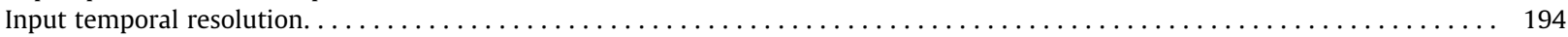

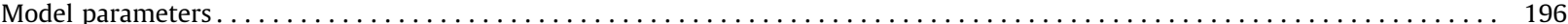

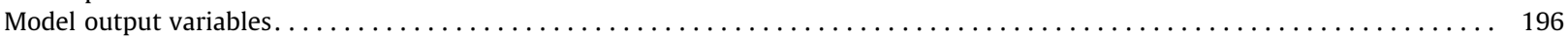

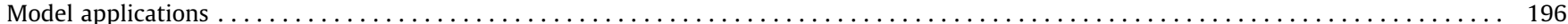

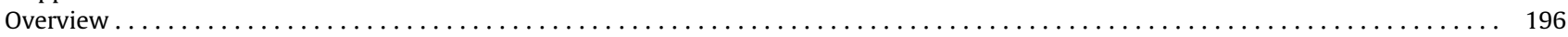

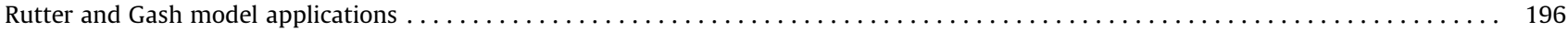

\footnotetext{
* Corresponding author. Tel.: +34 934095410; fax: +34 934110012.

E-mail addresses: amuzylo@ija.csic.es (A. Muzylo), pllorens@ija.csic.es (P. Llorens), fvalente@isa.utl.pt (F. Valente), jjkeizer@ua.pt (J.J. Keizer), poveda@eeza.csic.es (F. Domingo), jhg@ceh.ac.uk (J.H.C. Gash).
} 


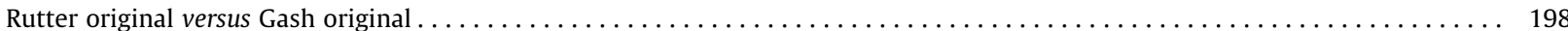

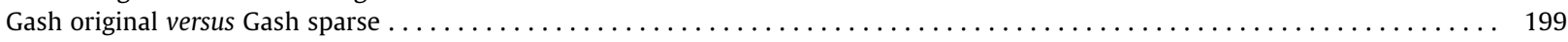

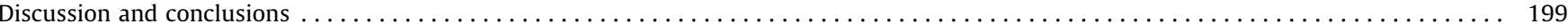

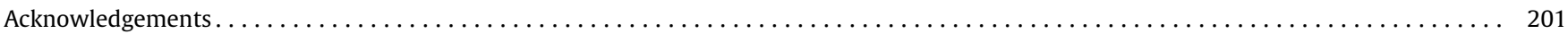

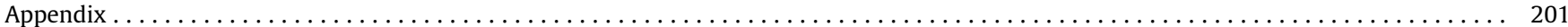

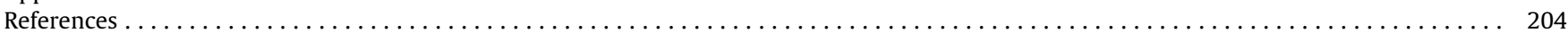

\section{Introduction}

Rainfall interception is the process by which gross rainfall falling onto vegetative surfaces is subsequently redistributed. The rain that hits plant surfaces is temporarily retained and, ultimately, either evaporates into the atmosphere (interception loss) or makes its way to the ground either by falling as drops (drip) or by flowing down branches and stems (stemflow). The rain that does not hit a plant surface is called free throughfall and, together with drip, is often referred to as throughfall (David et al., 2005). Throughfall and stemflow together are referred to as net rainfall. Interception loss depends strongly on the timing and intensity of rainfall, the vegetation structure and the meteorological conditions controlling evaporation during and after rainfall (Rutter et al., 1975; Ward and Robinson, 1990; Dingman, 2002; Brutsaert, 2005).

Rainfall interception is recognized as a hydrological process of considerable importance in water resource management, but also in the context of climate change (Arnell, 2002). This is especially true for forest stands, where annual interception loss commonly amounts to a quarter or more of total rainfall (Dingman, 2002). Evaporation rates of intercepted water are much higher for forest than for short vegetation, because forest has markedly higher aerodynamic conductance. Unlike short vegetation, evaporation rates of intercepted water from tall vegetation thus greatly exceed transpiration rates under identical conditions because there is no physiological control by the plants. Hence, interception loss can be regarded as a substantial net addition to transpiration (Rutter, 1967; Stewart, 1977; Calder, 1979). Evaporation of intercepted rainfall contributes significantly to the differences in water use found for different vegetation types (Calder, 1990). The various components of the rainfall interception process have been measured and modelled for many vegetation types, with a special emphasis on forest stands. Interception measurement studies have been extensively reviewed, the most recent examples being by Crockford and Richardson (2000), Dunkerley (2000), Levia and Frost $(2003,2006)$ and Llorens and Domingo (2007). However, a comprehensive review of interception modelling studies has not yet been published. The present attempt is motivated first and foremost by the widely recognized importance of rainfall interception models for predicting the effects of climate and landcover changes on water resources. Apart from allowing extrapolation of measurement results in space as well as time, interception models also provide insights into the mechanisms of the interception process (David et al., 2005).

The first attempt to conceptually model interception loss was by Horton (1919, also reproduced by Gash and Shuttleworth, 2007). However, until the 1970s, interception loss was predicted using empirically-derived relationships with gross rainfall. These relationships emphasized a species-dependent character of the interception process. Classic examples are the equations by Merriam (1960) and Zinke (1967). A major drawback of empirical models is that, as they are highly data set-specific, they cannot be confidently applied where conditions are distinctly different, particularly in terms of rainfall regime and vegetation type (Massman, 1983; Dingman, 2002). The first conceptual model, after Horton's work, to describe interception as a process driven by evaporation was put forward in the early 1970 s by Rutter et al. (1971). The complete version of the model, with an added stemflow compo- nent, soon followed (Rutter et al., 1975). At present, well over 15 physically-based interception models exist.

The objective of this paper is to provide a review of physicallybased interception modelling that addresses not only the models themselves, but also their application to field data sets. In the next two sections, a general description of the models is followed by a comparison of key model features. The following section concerns the model applications, and the final section addresses the main limitations in current process descriptions and the principal gaps in model assessment.

\section{Selection of interception models and their applications}

The Scopus data base (www.scopus.com) was searched using various combinations of the terms 'rainfall', 'interception', 'partitioning' and 'model(ling)'. From the over 200 bibliographic references found, nearly 80 scientific articles published in SCI journals before March 2008 were retained for this review.

The retained articles were screened for interception models that were not included in a preliminary listing of models previously compiled by the authors. Given the importance of interception loss for tall plants, only the models that explicitly address the interception loss component were retained for this review. Thus, the models of Ploey (1982), Bussière et al. (2002) and Castro et al. (2006) were disregarded because they covered just a part of the interception process and did not model the evaporation; the model proposed by Kozak et al. (2007) was not included because it is explicitly designed for short vegetation. The Groen and Savenije (2006) model, though an interesting approach, was not included in the review, either, as it extends rainfall interception to all wetted surfaces (canopy, understorey, forest floor, litter and soil). Of the most recent models, published after 2005, only that of Murakami (2007) is fully addressed in the review sensu stricto, but those of Groen and Savenije (2006) and Wang et al. (2007) are considered in the final section.

In all, 15 physically-based models were selected, to represent distinct conceptualizations of the interception process, published before 2008. Ten models are designated as 'original models', and five as significantly 'improved' variants of these original models. In chronological order of publication, the original models are the following: Rutter (Rutter et al., 1971, 1975), Gash (1979), Massman (1983), Mulder (1985), Calder one-layer (Calder, 1986), Liu J. (Liu, 1988), Liu S. (Liu, 1997), Xiao (Xiao et al., 2000), Zeng (Zeng et al., 2000) and Murakami (2007). In the same order, the 'improved' models are the following: Sellers and Lockwood (1981), sparse Gash (Gash et al., 1995), Calder two-layer (Calder, 1996), sparse Rutter (Valente et al., 1997) and van Dijk and Bruijnzeel (2001a).

The 15 models under review can be divided into two main groups. The first group deals with the interception of rainfall drops using probability distribution, whereas the second group deals with the redistribution of rainfall volume using a mass balance equation. This first group is restricted to two models, the Calder one- and two-layer models. The remaining models can be further sub-divided according to whether they employ a continuous, running water balance approach or, instead, an analytical solution to this approach. Following the first exponents of both approaches, the former models will be referred to here as Rutter-type models and the latter as Gash-type models (Table 1). 
Table 1

Principal characteristics of reviewed models. $\mathrm{I}=$ interception loss, $\mathrm{Tf}=$ throughfall, $\mathrm{Sf}=$ stemflow .

\begin{tabular}{|c|c|c|c|c|c|c|c|c|c|}
\hline \multirow[t]{2}{*}{ Model } & \multicolumn{2}{|c|}{ Input temporal scale ${ }^{a}$} & \multicolumn{3}{|c|}{ Output variable } & \multirow[t]{2}{*}{ Number of parameters } & \multirow[t]{2}{*}{ Layers } & \multirow[t]{2}{*}{ Spatial scale } & \multirow[t]{2}{*}{ Reference } \\
\hline & Rainfall & Meteorological & $I$ & Tf & Sf & & & & \\
\hline \multicolumn{10}{|l|}{ Rutter-type } \\
\hline Rutter & Hourly $^{\mathrm{b}}$ & Hourly $^{\mathrm{b}}$ & $\mathrm{x}$ & $\mathrm{x}$ & $\mathrm{x}$ & 7 & 1 & Stand & Rutter et al. (1971) \\
\hline Sellers and Lockwood & Hourly & Hourly & $\mathrm{x}$ & $\mathrm{x}$ & & $2+4 \times \mathrm{n}^{\mathrm{c}}$ & Multiple & Stand & Sellers and Lockwood (1981) \\
\hline Massman & $10 \mathrm{~min}$ & $10 \mathrm{~min}$ & $\mathrm{x}$ & $\mathrm{x}$ & & 4 & 1 & Stand & Massman (1983) \\
\hline Liu J. & Daily & Not clear & $\mathrm{x}$ & & & $4+2 \times n^{c}$ & Multiple & Stand & Liu (1988) \\
\hline Liu S. & Hourly ${ }^{d}$ & Hourly $^{\mathrm{d}}$ & $\mathrm{x}$ & & & 3 & 1 & Stand & Liu (1997) \\
\hline Xiao & Hourly $^{\mathrm{d}}$ & Hourly $^{\mathrm{d}}$ & $\mathrm{x}$ & $\mathrm{x}$ & $\mathrm{x}$ & 14 & Multiple & Tree & Xiao et al. (2000) \\
\hline Rutter sparse & Hourly $^{\mathrm{b}}$ & Hourly $^{\mathrm{b}}$ & $\mathrm{x}$ & $\mathrm{x}$ & $\mathrm{x}$ & 5 & 1 & Stand & Valente et al. (1997) \\
\hline \multicolumn{10}{|l|}{ Gash - type } \\
\hline Gash & Hourly $^{\mathrm{d}}$ & Hourly & $\mathrm{x}$ & $\mathrm{x}$ & $\mathrm{x}$ & 4 & 1 & Stand & Gash (1979) \\
\hline Mulder & Daily & Daily & $\mathrm{x}$ & & & 2 & 1 & Stand & Mulder (1985) \\
\hline Gash sparse & Hourly $^{\mathrm{d}}$ & Hourly & $\mathrm{x}$ & $\mathrm{x}$ & $\mathrm{x}$ & 4 & 1 & Stand & Gash et al. (1995) \\
\hline Zeng & Hourly & Hourly & $\mathrm{x}$ & & & 3 & 1 & Stand & Zeng et al. (2000) \\
\hline van Dijk and Bruijnzeel & Daily & Hourly & $\mathrm{x}$ & $\mathrm{x}$ & $\mathrm{x}$ & 7 & 1 & Stand & van Dijk and Bruijnzeel (2001a) \\
\hline Murakami & Hourly $^{\mathrm{f}}$ & Hourly $^{g}$ & $\mathrm{x}$ & & & 4 & 1 & Stand & Murakami (2007) \\
\hline Calder stochastic & Hourly ${ }^{\mathrm{b}}$ & Hourly $^{\mathrm{b}}$ & $\mathrm{x}$ & & & 6 & 1 & Stand & Calder (1986) \\
\hline Calder two-layer & Hourly ${ }^{b}$ & Hourly $^{\mathrm{b}}$ & $\mathrm{x}$ & & & 16 & 2 & Stand & Calder (1996) \\
\hline
\end{tabular}

a Minimum to meet the model's requirements.

b High resolution of calculations.

c $n$ number of layers.

d Or daily or event.

e From hourly to yearly.

f And daily.

g Not necessary if $E$ rate obtained from regression.

The five improved models involve modifications to the corresponding original models that are all related to vegetation stand characteristics, in particular to the spatio-temporal variation in them. Three types of modification can be discerned, i.e. those concerning the vegetation's horizontal structure (open or sparse vs. closed stands), its vertical structure (multi-layer vs. single-layer) and its temporal variation (dynamic vs. static cover).

\section{Model descriptions}

\section{Original models}

Rutter et al. (1971) were the first to present a conceptual, physically-based model. The Rutter model represents the interception process by a running water balance of rainfall input, storage and output in the form of drainage and evaporation. Since drainage and evaporation rates both depend on the amount of water stored in the canopy, they vary throughout the event. Rutter et al. (1975) developed the model's definitive version by adding a stemflow module, in which a fraction of the rainfall input is directly diverted to a compartment comprising the trunks. Early applications of Rutter-type models were made by Calder (1977) and Gash and Morton (1978).

Subsequent Rutter-type models were proposed by Massman (1983), Liu (1988), Liu (1997) and Xiao et al. (2000). The Massman model differs from the Rutter model in its drainage and evaporation equations (see “" Model comparison"). A fundamental difference of the Liu (1988) model from the other Rutter-type models is that it includes multiple canopy layers and, thus, progressive wetting of the canopy as water 'falls' from one layer to the other. Very recently, the Liu J. model was developed further to deal with heterogeneous canopies (Liu and Liu, 2008). The Liu S. model was explicitly designed to minimize data input requirements. It differs from the Rutter model in the way it deals with trunk interception and canopy wetting (Liu, 2001). The Xiao model was developed for estimating interception from single trees. It differs from the other Rutter-type models in that it covers the three-dimensional canopy architecture and thus requires special canopy architecture parameters.
Almost a decade after the original Rutter model was developed, Gash (1979) put forward the first analytical interception model, providing a simplified solution to the Rutter model. The Gash model represents rainfall input as a series of discrete storms that are separated by intervals sufficiently long for the canopy and stems to dry completely - this assumption is possible because of the rapid drying of forest canopies. Each individual storm is then divided into three subsequent phases - canopy wetting-up, saturation and drying. This separation emphasizes the relative importance of the climate against plant structure. For the first two of these phases, the actual rates of evaporation and rainfall are replaced by their mean rates for the entire period being modelled.

Subsequent Gash-type models were developed by Mulder (1985) and, much more recently, by Zeng et al. (2000) and Muraka$\mathrm{mi}$ (2007). The first two models maintain the original three storm phases, but introduce modifications. The Mulder model uses distinct evaporation rates for wet conditions (phases 1 and 2) and dry conditions (phase 3), whilst the Zeng model takes into account the statistical characteristics of rainfall input. Unlike the other models, the Murakami model does not distinguish different storm phases. It derives evaporation rates from observed rainfall data and, to this end, also explicitly deals with splash droplet evaporation.

Calder (1986) developed a distinct model of the interception process that is conceptually very different from Rutter- and Gash-type models. The Calder model employs Poisson probability distribution to determine the number of raindrops that strike the canopy and are retained by it. The stored canopy water is then removed by evaporation or, whenever the storage threshold is exceeded, routed to the ground as drainage.

\section{Improved models}

The sparse versions of Gash and Rutter models were proposed by Gash et al. (1995) and Valente et al. (1997), respectively, to adjust the original model formulations to forest stands with significant open spaces between the tree canopies. At the same time, some minor corrections were introduced. A crucial change is that in the sparse versions the evaporation rate from wetted surfaces 
is no longer calculated for the entire plot area, but only for the area that is covered by the canopy. This change overcame a poor boundary condition in the original models whereby the modelled canopy failed to wet up beyond a certain degree of sparseness. Both model versions provide similar results for closed canopies, as the sparse versions converge to the original models when the canopy cover approaches unity.

van Dijk and Bruijnzeel (2001a) adapted the sparse Gash model for vegetation whose characteristics change markedly during the growing season. The key amendment of the van Dijk and Bruijnzeel model is the use of time-variant model parameter values. In their study (van Dijk and Bruijnzeel, 2001b) calculated these parameter values as functions of the Leaf Area Index as it changes during the crop cycle.

Model variants accommodating multiple vegetation layers were developed by Sellers and Lockwood (1981) for the Rutter model; and by Calder (1996), for the Calder one-layer model. Both multilayer models determine storage and drainage for each of the vegetation layers individually. In the Sellers and Lockwood model, this involves assessing the evaporation rate of each layer on the basis of the Penman-Monteith equation (Monteith, 1965). In the Calder two-layer model, the kinetic energy of the throughfall drops falling on the lower layer is a key element in assessing changes in the layer's storage and drainage.

\section{Model comparison}

Ten model characteristics were chosen to convey the essential differences between the selected models (Table 1 ). These characteristics can be divided into two groups. Those that concern model structure and processes are taken up first, and those that concern model input, parameters and output are analysed afterwards.

\section{Model structure and processes}

\section{Spatial extent}

All but one of the selected models predict interception loss at the spatial scale of individual vegetation stands, whereas the Xiao model deals with individual trees. The 'sparse' models divide the stands into one part with a uniform closed canopy and an open part without any canopy. In contrast, the remaining models treat the stands as homogeneous intercepting areas.

\section{Canopy drainage}

Canopy drainage is explicitly represented in eight of the models. Two main approaches can be distinguished. The Rutter original and Massman model estimate drainage as a function of time that is based on empirical relationships, whereas the other models (the Rutter sparse, both Gash models, Mulder, Xiao and Calder twolayer models) treat drainage as an integral part of the canopy water balance.

The Rutter model computes drainage by multiplying an empirically-based drainage rate by a coefficient that relates drainage rate to canopy storage. Drainage in the Rutter model can therefore continue after rainfall has ceased. Massman (1983) proposed a different approach, in which drainage rate depends directly on rainfall intensity. The sparse Rutter model uses a more straightforward drainage formulation than the original model, thereby avoiding the above-mentioned empirical parameter. It involves determining the difference between the canopy's storage and its storage capacity, and converting any surplus storage directly into drainage. Thus, unlike the original Rutter model, in the sparse variant drainage automatically stops as soon as the rainfall ends. The Xiao model stands out amongst the other models in that it takes rainfall angle of incidence and leaf inclination as important factors affecting drainage.

Though Calder (1986) did not explicitly include drainage in his one-layer model, he admitted that estimating it from canopy storage would improve model results. The model's follow-up, twolayer version does in fact include drainage, representing it as the falling of drops from the upper layer. The improved model ignores drainage after cessation of rainfall, but just for practical reasons, i.e. because it is not a significant part of the interception process.

\section{Maximum wet canopy evaporation rate}

Evaporation of intercepted rain from canopy and/or stems is calculated by means of the Penman-Monteith formulation (Monteith, 1965) in almost all the 15 models. Only the Massman, Murakami and Xiao models do not follow this approach. It is generally acknowledged that setting the canopy resistance in this equation to zero provides a good approximation of the evaporation rate from a completely wet canopy (Gash et al., 1980), which is normally referred to as 'maximum wet canopy evaporation rate'. The Xiao model uses the adapted Penman (1948) equation rather than the equation modified by Monteith. Massman (1983) developed an alternative formulation that overcomes the high data input requirements of the Penman-Monteith equation. However, it has received little attention. The two key assumptions underlying Massman's equation are that: (i) thermal diffusivity is constant over the entire tree canopy depth and (ii) the Bowen ratio and other micrometeorological parameters can be appropriately averaged over the duration of a rainstorm. As highlighted by the author himself, this equation is especially suited to forest stands that have deep canopies with fairly large temperature gradients.

The Murakami model is exceptional in employing observed, rather than modelled, wet evaporation rates. The author argues that the Penman-Monteith equation does not take into account evaporation from splash droplets, and thus ignores an important process, particularly for climates typified by intense storms with high rainfall rates. An obvious drawback of this approach is its empirical nature.

\section{Pre-event canopy and stem storage}

Canopy and stem storage compartments are assumed to be empty at the onset of each storm in all analytical models (excepting the Mulder model) and in the two Calder models. In other words, generally for the Gash-type and Calder models individual storms have, by definition, a fully-closed water balance. The running water balance approach makes the Rutter-type models, in this respect, less restrictive.

\section{Model input, parameters and output}

\section{Input temporal resolution}

The Massman model is exceptional in that it requires rainfall data with a temporal resolution of $10 \mathrm{~min}$ as opposed to the hourly or daily rainfall values required by the 14 other models (Table 1). The sparse and original Gash models and the Liu S. model may equally use event-wise rainfall data as input. In all models except three, if the meteorological input data are used to estimate evaporation rates, their requirements are the same as the minimum requirements for temporal resolution of the rainfall data (Table 1). These exceptions are the van Dijk and Bruijnzeel and two Gash models, which require meteorological records with a higher temporal resolution than the rainfall records. It should be pointed out that the mean wet-canopy evaporation rate required for the storm-based models can be obtained from a regression of interception on rainfall, thereby removing the requirement for meteorological data. 
Table 2

Parameters used in the reviewed models. Values in the columns reflects the number of required parameters within each parameter type.

\begin{tabular}{|c|c|c|c|c|c|c|c|c|c|c|c|c|c|c|c|c|}
\hline \multirow{2}{*}{$\begin{array}{l}\text { Parameters } \\
\text { related to }\end{array}$} & \multirow[t]{2}{*}{ Parameter } & \multicolumn{7}{|c|}{ Rutter-type models } & \multicolumn{6}{|c|}{ Gash-type models } & \multicolumn{2}{|c|}{ Calder models } \\
\hline & & $\begin{array}{l}\text { Rutter } \\
\text { et al. } \\
(1971 \text {, } \\
1975)\end{array}$ & $\begin{array}{l}\text { Sellers and } \\
\text { Lockwood } \\
(1981)\end{array}$ & $\begin{array}{l}\text { Massman } \\
(1983)\end{array}$ & $\begin{array}{l}\text { Liu J. } \\
\text { (1988) }\end{array}$ & $\begin{array}{l}\text { Liu S. } \\
\text { (1997) }\end{array}$ & $\begin{array}{l}\text { Rutter sparse } \\
\text { (Valente et al., } \\
\text { 1997) }\end{array}$ & $\begin{array}{l}\text { Xiao } \\
\text { et al. } \\
\text { (2000) }\end{array}$ & $\begin{array}{l}\text { Gash } \\
(1979)\end{array}$ & $\begin{array}{l}\text { Mulder } \\
(1985)\end{array}$ & $\begin{array}{l}\text { Gash sparse } \\
\text { (Gash et al., } \\
1995 \text { ) }\end{array}$ & $\begin{array}{l}\text { Zeng } \\
\text { et al. } \\
\text { (2000) }\end{array}$ & $\begin{array}{l}\text { van Dijk and } \\
\text { Bruijnzeel } \\
\text { (2001a) }\end{array}$ & $\begin{array}{l}\text { Murakami } \\
(2007)\end{array}$ & $\begin{array}{l}\text { Calder } \\
(1986)\end{array}$ & $\begin{array}{l}\text { Calder } \\
(1996)\end{array}$ \\
\hline \multirow[t]{5}{*}{ Water storage } & Max depth of canopy storage & & & & & 1 & & 1 & & & & & & 1 & 1 & $3^{a b c}$ \\
\hline & $\begin{array}{l}\text { Canopy storage capacity } \\
\text { Water storage }^{\mathrm{d}}\end{array}$ & 1 & 1 & 1 & 1 & & 1 & 1 & 1 & 1 & 1 & 1 & 1 & & & \\
\hline & Specific storage & & & & 1 & & & & & & & & 1 & & & \\
\hline & Leaf wetted area coefficient & & 1 & & & & & & & & & & & & & \\
\hline & Trunk storage capacity & 1 & & & & & & & 1 & & & & 1 & & & \\
\hline \multirow[t]{9}{*}{ Canopy structure } & Canopy cover & & & & 1 & & 1 & & & & 1 & 1 & 1 & 1 & & $3^{e}$ \\
\hline & Free throughfall coefficient & 1 & $2^{f}$ & 1 & & 1 & & 1 & 1 & 1 & & & 1 & & & \\
\hline & $\begin{array}{l}\text { Branch, stem, leaf or total area } \\
\text { index }\end{array}$ & & $1^{\mathrm{f}}$ & & $2^{f}$ & 1 & & 2 & & & & & 1 & 1 & & \\
\hline & Number of elemental surfaces & & & & & & & & & & & & & & 1 & 1 \\
\hline & Average leaf surface & & & & & & & 1 & & & & & & & & \\
\hline & Surface area density & & & & 1 & & & & & & & & & & & \\
\hline & Leaf inclination angle & & & & & & & 2 & & & & & & 1 & & \\
\hline & Stem inclination angles & & & & & & & 2 & & & & & & & & \\
\hline & $\begin{array}{l}\text { Normal and effective stem and } \\
\text { crown projection area }\end{array}$ & & & & & & & 4 & & & & & & & & \\
\hline \multirow[t]{5}{*}{ Water partitioning } & Drip parameters & & & 2 & & & & & & & & & & & & \\
\hline & $\begin{array}{l}\text { Canopy drainage coefficient } \\
\text { Drainage partitioning } \\
\text { coefficient }\end{array}$ & 2 & $1^{\mathrm{f}}$ & & & & 1 & & & & 1 & & & & & \\
\hline & $\begin{array}{l}\text { Stemflow partitioning } \\
\text { coefficient }\end{array}$ & 1 & & & & & & & 1 & & & & 1 & & & \\
\hline & $\begin{array}{l}\text { Fraction of rain striking top } \\
\text { layer }\end{array}$ & & & & & & & & & & & & & & & 1 \\
\hline & $\begin{array}{l}\text { Fraction of shed rain from the } \\
\text { top layer striking bottom layer }\end{array}$ & & & & & & & & & & & & & & & 1 \\
\hline \multirow[t]{8}{*}{ Other } & Number of drops & & & & & & & & & & & & & & 1 & \\
\hline & $\begin{array}{l}\text { Mean number of drops } \\
\text { retained per element }\end{array}$ & & & & & & & & & & & & & & 1 & \\
\hline & $\begin{array}{l}\text { Max number of drops retained } \\
\text { per element }\end{array}$ & & & & & & & & & & & & & & 1 & $1^{\mathrm{g}}$ \\
\hline & Mean raindrop volume & & & & & & & & & & & & & & 1 & $2^{\mathrm{h}}$ \\
\hline & Characteristic volume $\mathrm{e}^{\mathrm{i}}$ & & & & & & & & & & & & & & & 3 \\
\hline & $\begin{array}{l}\text { Parameters governing kinetic } \\
\text { dependence of } \mathrm{Cm} \mathrm{Cmax} \text { as a } \\
\text { function of volume }\end{array}$ & & & & & & & & & & & & & & & \\
\hline & Threshold of rainfall intensity & & & & & & & & & & & 1 & & & & \\
\hline & Constant between $\mathrm{Et} / \mathrm{Ec}$ & 1 & & & & & 1 & & & & & & & & & \\
\hline
\end{tabular}

For zero kinetic energy drops.

Achievable for the two-layer formulation with zero kinetic energy drops incident on the top layer.

Achievable for the two-layer formulation with non-zero kinetic energy drops incident on the top layer.

In unit volume of canopy.

And for the top and bottom layer.

feferred to the $n$ layer.

For non-zero kinetic energy drops.

For zero and non-zero kinetic energy drops.

Of drops falling from vegetation. 


\section{Model parameters}

The total number of model parameters varies considerably from model to model (Table 1). In the case of the single-layer models, the number varies from 2 to 7 , and in the case of the multi-layer models, from 8 to 16 for stands comprising two layers. The model parameters themselves are shown in Table 2, where they are grouped in four main categories. A selection of these parameters - i.e. those that are common to most of the models - will be addressed in more detail in the following paragraphs.

All 15 models include some parameter representing the storage of intercepted rain in the canopy or, to be more specific, the threshold amount of rain that can be stored in the canopy. The analogous designations of this storage threshold are misleading, because its exact definition may differ significantly between models. For example, in the original and sparse Rutter and Gash models, it is defined as the minimum amount of intercepted rain that is necessary to saturate the canopy, whereas in the Calder one-layer model it is defined as the maximum number of drops that can be retained by any canopy element, multiplied by the drops' mean volume. It may also be misleading that the canopy storage parameter may apply to different parts of the vegetation stand. For example, it refers to the entire plot area in the case of the original Rutter and Gash models, but, in the case of the models' sparse variants, only to the part of the plot covered by the canopy or, in the case of the Liu J. model, to a unit volume of canopy. Further information on the canopy storage parameter is given by Klaassen et al. (1998).

The 15 models also all include a parameter describing the structure of the canopy (Table 2). The bulk of the Rutter- and Gash-type models employ the free throughfall coefficient to partition the throughfall, but in the sparse versions the canopy cover fraction is used to partition the evaporation. In practice, however, this distinction is often ignored with the free throughfall coefficient being determined as ( 1 - canopy cover fraction). The two Calder models stand out because they require a parameter that describes the number of elemental surface areas per unit of ground area. Conceptually, this parameter is highly specific to the Calder models, but the existing applications of the Calder model generally derive its value from the Leaf Area Index (LAI). This same LAI is also used in applications of the Liu J., Liu S., Sellers and Lockwood, and van Dijk and Bruijnzeel models.

\section{Model output variables}

Half of the selected models predict throughfall and stemflow as well as interception loss (Table 1). In the models that do not explicitly model throughfall and stemflow, the water balance equation can be used to estimate at least net rainfall (i.e. throughfall + stemflow).

\section{Model applications}

The selected articles were analysed individually for a series of key features concerning the application of the 15 interception models to field data sets. These key features are: (i) the model(s) tested; (ii) the country, region, climate and vegetation type studied; (iii) the duration of the modelling period; (iv) the method of estimating the maximum evaporation rate; (v) model validation and success.

For obvious reasons, climate and vegetation type need to be standardized. To this end, Köppen's climate classification (McKnight and Hess, 2000) was used and six physiognomicallybased vegetation types were distinguished (rainforest, conifers, hardwoods, mixed conifer and hardwoods, shrubs, crops). The length of the modelling period was standardized to five classes (less than or equal to $1,3,6$ or 12 months, and more than 1 year). Two types of model assessment were recognized, depending on whether or not separate data sets were used for calibrating the model(s) or optimizing model parameter values. In the case of separate data sets, the model is designated as "calibrated and validated'. Model success is defined here as the absolute difference between predicted and observed interception loss. In several of the reviewed articles (Table 3 ), this measurement was not given in the original papers and could not be calculated from the figures shown. In these instances, model success was simply given as unspecified or as under- or over-estimated. In the other cases, model error is classified in eight numerical and five qualitative groups. Whilst the former are given with a table (see Appendix), the latter are as follows: bad (error $>30 \%$ of measured interception loss); fair $(10 \%<$ error $\leqslant 30 \%)$; good $(5 \%<$ error $\leqslant 10 \%)$; very good $(1 \%<$ error $\leqslant 5 \%)$; extremely good (error $\leqslant 1 \%<$ error). If applicable, model error refers to the results of model validation rather than calibration, and to the best of multiple results.

\section{Overview}

As shown in Fig. 1, the bulk of the selected model applications involve the original and sparse Gash models (69 cases) and, to a lesser extent, the original and sparse Rutter models (42 cases). The Mulder model was applied in four studies; the remaining 10 models have received even less attention (Fig. 1 and Table 3 ). In view of these numbers, it was decided to limit the more detailed review of the application studies in the next section to the two versions of the Gash and Rutter models.

Three-quarters of the model applications are about equally divided between three of the vegetation types, i.e. rainforest, conifer and hardwood stands. Not surprisingly, however, there are clear geographical differences in the study of the various vegetation types (Fig. 2). Modelling studies in Central and South America and in Asia have clearly focused on rainforests, whilst those in Europe and Africa have concentrated on conifers and crops, respectively. In North America, research attention has been divided more evenly between shrubs, conifers and hardwoods.

Europe has seen a larger number of model applications than the other geographic regions (Fig. 2). This may be because most of the 15 models were developed at European research institutes. In contrast, comparatively few application studies deal with Africa or Central and South America, which as expected coincides with a general tendency in scientific research.

\section{Rutter and Gash model applications}

As mentioned before, the two variants of the Gash model have been tested together more often than the Rutter model variants (69 vs. 42 instances; see Appendix, Table 4). This difference is more accentuated in the case of the sparse variants, with 41 sparse Gash applications against only six sparse Rutter applications. The much lower application of the sparse Rutter model than the sparse Gash model contrasts strongly with the roughly similar numbers of applications of the original variants (Gash: 28; Rutter: 36). The difference in publication dates of the sparse versions (Gash et al., 1995; Valente et al., 1997) does not offer a satisfactory explanation. What may have happened, however, is steady abandonment of the running-balance approach in favor of the simpler analytical approach, possibly motivated by the satisfactory results obtained with the original Gash model. Furthermore, the use of a regression between rainfall and interception to derive evaporation rate can make application of the Gash model possible in places where only rainfall data are available - often an attractive option for sparsely instrumented watersheds. The numerous applications of the Gash model derived from regression, even if this was not intended by Gash (1979), support this argument (see Table 4). 
Table 3

Complete list of applications. R-Rutter models, G-Gash models, M-Mulder model, L-Liu S. model, C-Calder models, SL-Sellers and Lockwood model.

\begin{tabular}{|c|c|c|c|c|c|c|c|c|c|c|c|c|c|c|}
\hline \multirow[t]{2}{*}{ In-text reference } & \multicolumn{6}{|c|}{ Model } & \multirow[t]{2}{*}{ Country } & \multirow[t]{2}{*}{ Region } & \multicolumn{6}{|c|}{ Vegetation cover } \\
\hline & $\mathrm{R}$ & G & M & $\mathrm{L}$ & $\mathrm{C}$ & SL & & & Conifer & Hardwood & Mixed & Shrub & Agriculture & Rainforest \\
\hline Aboal et al. (1999) & $\mathrm{x}$ & $\mathrm{x}$ & & & & & Spain & Canary Island & & $\mathrm{x}$ & & & & \\
\hline Asdak et al. (1998) & $\mathrm{x}$ & $\mathrm{x}$ & & & & & Indonesia & Centr. Kalimantan & & & & & & $\mathrm{x}$ \\
\hline Bigelow (2001) & $\mathrm{x}$ & & & & & & Costa Rica & & & $\mathrm{x}$ & & & & \\
\hline Bringfelt and Lindroth (1987) & $\mathrm{x}$ & & & & & & Sweden & Northern & $\mathrm{x}$ & & & & & \\
\hline Bryant et al. (2005) & & $\mathrm{x}$ & & & & & USA & Georgia & $\mathrm{x}$ & $\mathrm{x}$ & $\mathrm{x}$ & & & \\
\hline Calder et al. (1986) & $\mathrm{x}$ & & & & $\mathrm{x}$ & & Indonesia & W Java & & & & & & $\mathrm{x}$ \\
\hline Carlyle-Moses and Price (1999) & & $\mathrm{x}$ & & & & & Canada & Ontario & & $\mathrm{x}$ & & & & \\
\hline Carlyle-Moses and Price (2007) & & $\mathrm{x}$ & & $\mathrm{x}$ & & & Mexico & Sierra Madre & & & $\mathrm{x}$ & & & \\
\hline Cooper and Lockwood (1987) & & & & & & $\mathrm{x}$ & - & - & & & & & & \\
\hline Cuartas et al. (2007) & $\mathrm{x}$ & $\mathrm{x}$ & & & & & Brazil & Central Amazonas & & & & & & $\mathrm{x}$ \\
\hline Davie and Durocher (1997) & $\mathrm{x}$ & & & & & & Simulated data & & & & & & & \\
\hline Deguchi et al. (2006) & & $\mathrm{x}$ & & & & & Japan & Central & & $\mathrm{x}$ & & & & \\
\hline van Dijk and Bruijnzeel (2001b) & & $\mathrm{x}$ & & & & & Indonesia & Java & & & & & $\mathrm{x}$ & \\
\hline Dolman (1987) & & $\mathrm{x}$ & $\mathrm{x}$ & & & & Netherlands & Coastal & & $\mathrm{x}$ & & & & \\
\hline Domingo et al. (1998) & $\mathrm{x}$ & & & & & & Spain & S-E & & & & $\mathrm{x}$ & & \\
\hline Dykes (1997) & & $\mathrm{x}$ & & & & & Brunei & $\mathrm{N}-\mathrm{W}$ & & & & & & $\mathrm{x}$ \\
\hline Eltahir and Bras (1993) & $\mathrm{x}$ & & & & & & Simulated data & & & & & & & \\
\hline Gash and Morton (1978) & $\mathrm{x}$ & & & & & & UK & East Anglia & $\mathrm{x}$ & & & & & \\
\hline Gash (1979) & & $\mathrm{x}$ & & & & & UK & East Anglia & $\mathrm{x}$ & & & & & \\
\hline Gash et al. (1980) & $\mathrm{x}$ & $\mathrm{x}$ & & & & & UK & Wales,Scotland & $\mathrm{x}$ & & & & & \\
\hline Gash et al. (1995) & & $\mathrm{x}$ & & & & & France & S-W & $\mathrm{x}$ & & & & & \\
\hline Gash et al. (1999) & $\mathrm{x}$ & & & & & & Portugal & Central & $\mathrm{x}$ & & & & & \\
\hline Germer et al. (2006) & & $\mathrm{x}$ & & & & & Brazil & Rodonia & & & & & & $\mathrm{x}$ \\
\hline Hall et al. (1996) & $\mathrm{x}$ & & & & $\mathrm{x}$ & & Sri Lanka & Upper Mahaweli & & & & & & $\mathrm{x}$ \\
\hline Herbst et al. (2006) & & $\mathrm{x}$ & & & & & UK & S England & & $\mathrm{x}$ & & & & \\
\hline Holscher et al. (2004) & & $\mathrm{x}$ & & & & & Costa Rica & Talamanca & & & & & & $\mathrm{x}$ \\
\hline Hormann et al. (1996) & & $\mathrm{x}$ & & & & & Germany & North & & $\mathrm{x}$ & & & & \\
\hline Hutjes et al. (1990) & & $\mathrm{x}$ & $\mathrm{x}$ & & & & Ivory Cost & & & & & & & $\mathrm{x}$ \\
\hline Jackson (2000) & & $\mathrm{x}$ & & & & & Kenya & Nairobi & & & & & $\mathrm{x}$ & \\
\hline Jetten (1996) & $\mathrm{x}$ & & & & & & Guyana & Georgetown & & & $\mathrm{x}$ & & & \\
\hline Kozak et al. (2007) & & & & & & $\mathrm{x}$ & US & & & & & & $\mathrm{x}$ & \\
\hline & & & & & & $\mathrm{x}$ & Australia & & & & & & $\mathrm{x}$ & \\
\hline Lankreijer et al. (1993) & & $\mathrm{x}$ & $\mathrm{x}$ & & & & France & S-W & $\mathrm{x}$ & & & & & \\
\hline & & & & & & & Netherlands & Central & & $\mathrm{x}$ & & & & \\
\hline Lankreijer et al. (1999) & & $\mathrm{x}$ & & & & & Sweden & Uppsala & & & $\mathrm{x}$ & & & \\
\hline Link et al. (2004) & & $\mathrm{x}$ & & & & & USA & Pacific N-W & $\mathrm{x}$ & & & & & \\
\hline Liu (1997) & & & & $\mathrm{x}$ & & & USA & & $\mathrm{x}$ & $\mathrm{x}$ & & & & \\
\hline Llorens (1997) & & $\mathrm{x}$ & & & & & Spain & pre-Pyrenees & $\mathrm{x}$ & & & & & \\
\hline Lloyd et al. (1988) & $\mathrm{x}$ & $\mathrm{x}$ & & & & & Brazil & Manaus & & & & & & $\mathrm{x}$ \\
\hline Lockwood (1990) & & & & & & $\mathrm{x}$ & - & & & & & & & \\
\hline Lockwood (1992) & & & & & & $\mathrm{x}$ & - & & & & & & & \\
\hline Loescher et al. (2005) & $\mathrm{x}$ & & & & & & Costa Rica & Puerto Viejo & & & & & & $\mathrm{x}$ \\
\hline Loustau et al. (1992) & & $\mathrm{x}$ & & & & & France & Bordeaux & $\mathrm{x}$ & & & & & \\
\hline Mulder (1985) & & & $\mathrm{x}$ & & & & Netherlands & Castricum & $\mathrm{x}$ & & & & & \\
\hline Murakami (2007) & & $\mathrm{x}$ & & & & & Japan & Eastern & $\mathrm{x}$ & & & & & \\
\hline Navar and Bryan (1994) & & $\mathrm{x}$ & & & & & Mexico & Gulf Mexico & & & & $\mathrm{x}$ & & \\
\hline Navar et al. (1999b) & & $\mathrm{x}$ & & & & & Mexico & Gulf Mexico & & & & $\mathrm{x}$ & & \\
\hline Navar et al. (1999a) & & $\mathrm{x}$ & & & & & Mexico & Gulf Mexico & & & & $\mathrm{x}$ & & \\
\hline Pearce et al. (1980) & $\mathrm{x}$ & $\mathrm{x}$ & & & & & UK & Norfolk & $\mathrm{x}$ & & & & & \\
\hline Pearce and Rowe (1981) & & $\mathrm{x}$ & & & & & New Zeland & South Island & & & & & & $\mathrm{x}$ \\
\hline Price and Carlyle-Moses (2003) & & $\mathrm{x}$ & & & & & Canada & Ontario & & $\mathrm{x}$ & & & & \\
\hline Pypker et al. (2005) & & $\mathrm{x}$ & & & & & USA & Pacific N-W & $\mathrm{x}$ & & & & & \\
\hline Rao (1987) & & $\mathrm{x}$ & & & & & India & & & $\mathrm{x}$ & & & & \\
\hline Rowe (1983) & & $\mathrm{x}$ & & & & & New Zeland & South Island & & $\mathrm{x}$ & & & & \\
\hline Rutter et al. (1971) & $\mathrm{x}$ & & & & & & UK & & $\mathrm{x}$ & & & & & \\
\hline Rutter et al. (1975) & $\mathrm{x}$ & & & & & & UK & & $\mathrm{x}$ & & & & & \\
\hline Schellekens et al. (1999) & $\mathrm{x}$ & $\mathrm{x}$ & & & & & Puerto Rico & Loquillo & & & & & & $\mathrm{x}$ \\
\hline Schellekens (2000) & $\mathrm{x}$ & & & & & & Puerto Rico & Luquillo & & & & & & $\mathrm{x}$ \\
\hline Sraj et al. (2008) & & $\mathrm{x}$ & & & & & Slovenia & S-W & & $\mathrm{x}$ & & & & \\
\hline Tallaksen et al. (1996) & $\mathrm{x}$ & & & & & & Norway & Oslo & $\mathrm{x}$ & & & & & \\
\hline Tani et. al. (2003) & $\mathrm{x}$ & & & & & & Malasia & & & & & & & $\mathrm{x}$ \\
\hline Valente et al. (1997) & $\mathrm{x}$ & $\mathrm{x}$ & & & & & Portugal & Central & $\mathrm{x}$ & $\mathrm{x}$ & & & & \\
\hline Wallace and McJannet (2006) & & $\mathrm{x}$ & & & & & Australia & N Queensland & & & & & & $\mathrm{x}$ \\
\hline Wallace and Mcjannet (2008) & & $\mathrm{x}$ & & & & & Australia & N Queensland & & & & & & $\mathrm{x}$ \\
\hline Whelan and Anderson (1996) & $\mathrm{x}$ & & & & & & UK & Devon & $\mathrm{x}$ & & & & & \\
\hline Whitehead and Kelliher (1991) & $\mathrm{x}$ & & & & & & New Zealand & Rotorua & $\mathrm{x}$ & & & & & \\
\hline Zeng et al. (2000) & $\mathrm{x}$ & & & & & & Brazil & Central Amazon & & & & & & $\mathrm{x}$ \\
\hline & & & & & & & France & Les Landes & $\mathrm{x}$ & & & & & \\
\hline Zhang et al. (2006) & & $\mathrm{x}$ & & & & & China & Central-S & $\mathrm{x}$ & $\mathrm{x}$ & & & & \\
\hline
\end{tabular}



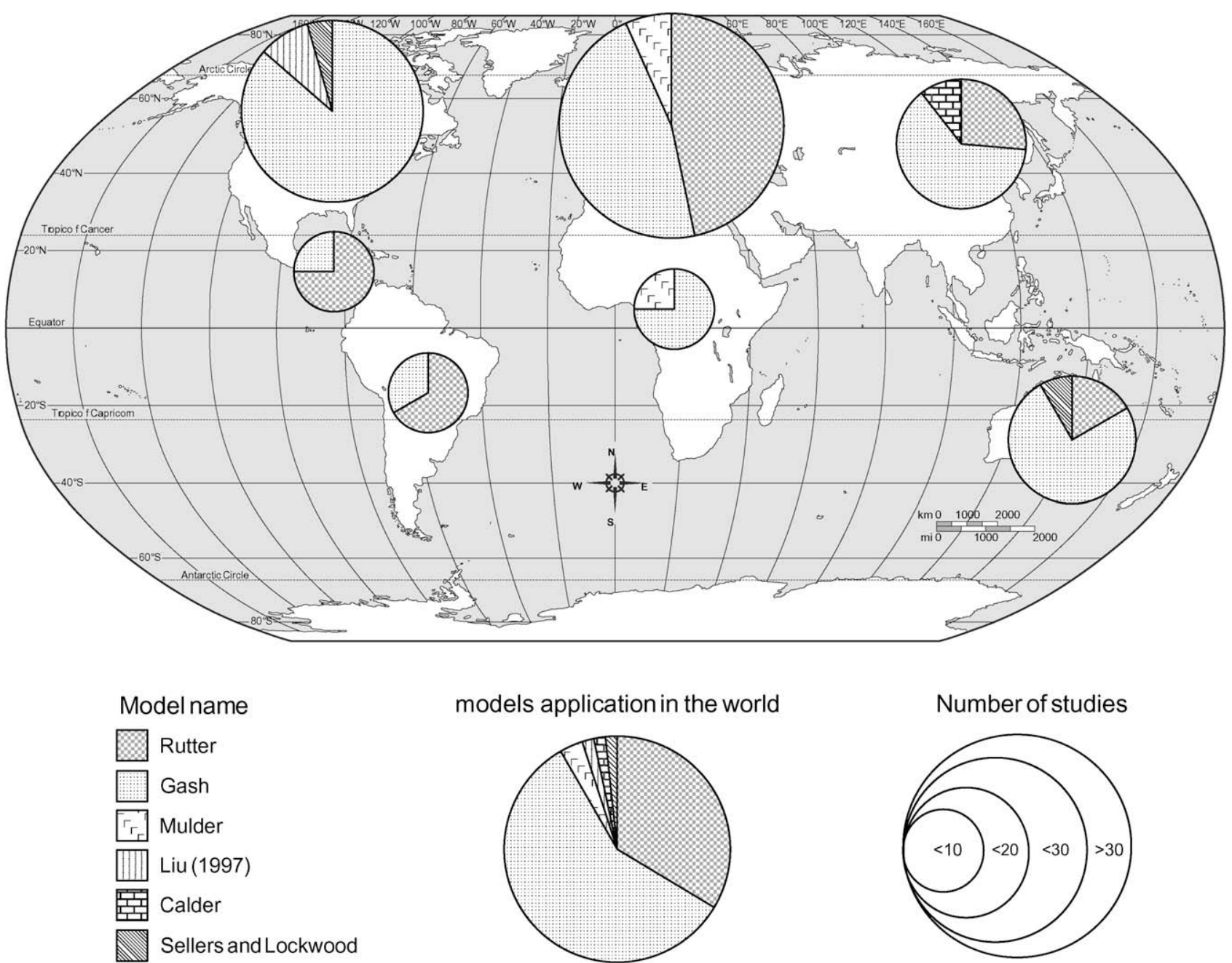

models application in the world

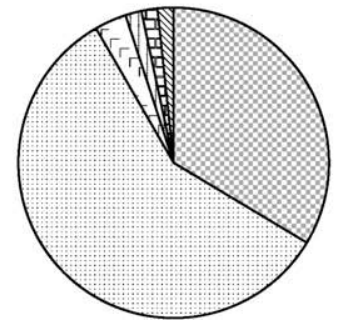

Number of studies

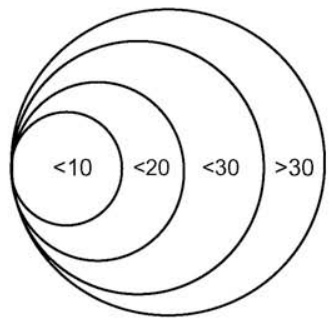

Fig. 1. Model applications in the world. Gash, Rutter and Calder model refers to the original and improved versions. Only applications with real data were considered.

Almost four-fifths of 111 Gash and Rutter applications either specify or allow the computation of the above-mentioned error in predicted interception loss. The quantitative performance of Gash and Rutter model applications is summarized in Fig. 3, which shows four of the five classes of quantitative error ('extremely good' and 'very good' were merged). Special attention is given to the model applications whose validation uses independent data sets (which, interestingly, are all studies of more than one year). In one case - that of the entire set of sparse Gash model applications - the four error classes reveal marked differences in the number of applications. A similar tendency toward very good results can also be observed for the 'validation' subset of sparse Rutter model applications, but its reduced sample size advises extra caution.

However, measurement errors are not usually taken into account in the discussion of modelling performance. Because interception is measured as the relatively small difference between gross and net rainfall, even small errors in these measurements can result in high relative errors in interception loss (Fig. 4). For instance, if gross rainfall and throughfall are both measured with $2.5 \%$ accuracy but interception loss is $15 \%$ of gross rainfall, one should expect an error of some $22 \%$ in the measured interception loss (Fig. 4). This is an important consideration when assessing the performance of models, as even quite large differences between predicted and observed interception loss can be less than the expected measurement error, limiting the conclusions that can be drawn. In the next two sections, the results obtained with the Rutter and Gash models will be analysed in more detail by comparing the two original models as well as the original and sparse variants of the Gash model. The other two possible comparisons are less interesting due to the above-mentioned, restricted number of sparse Rutter applications.

\section{Rutter original versus Gash original}

Thirty-five percent of the total number of original Rutter model applications did not specify the error obtained. However, all the original Gash applications indicated the error obtained. For both models, $6 \%$ of applications did not give a numerical estimate of the magnitude of the error.

However, fewer than $40 \%$ of these original model applications were validated with independent data sets. For these applications the number of very good performances (up to $5 \%$ ) were similar for both models, which was maintained for the other levels of goodness (Fig. 3). The similarities between the two models' applications are also found in the type of climate to which the models were mainly applied, which for both models is temperate, except that the Rutter model was more frequently used in tropical rainforest climates than the Gash model. The general similarities are also reflected in the vegetation types most frequently studied. The difference is that the Rutter model was applied predominantly in coniferous species, whereas the Gash model, as mentioned above, was applied in coniferous and hardwood species, too. 


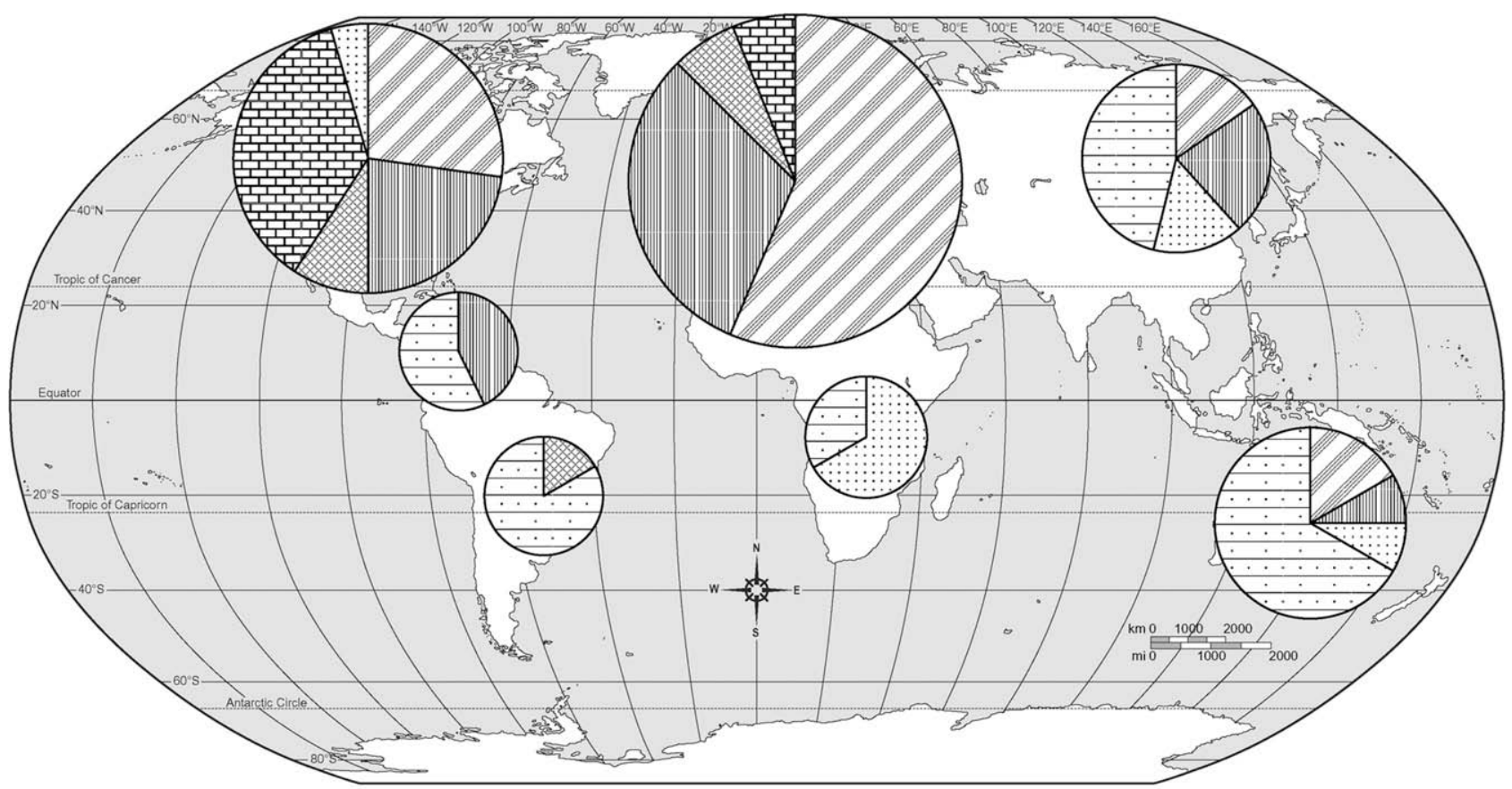

Vegetation type

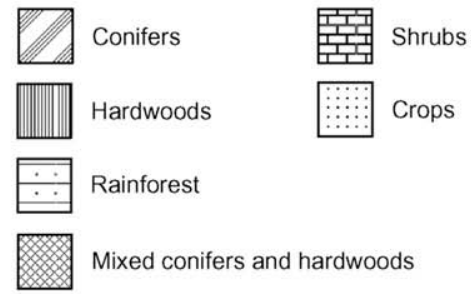

World total

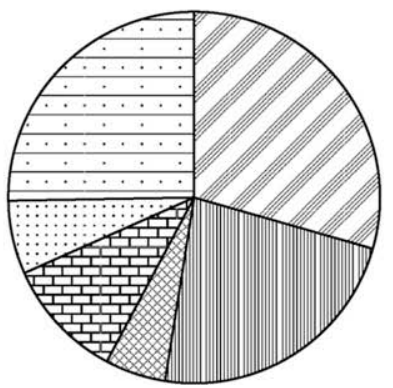

Number of studied plots

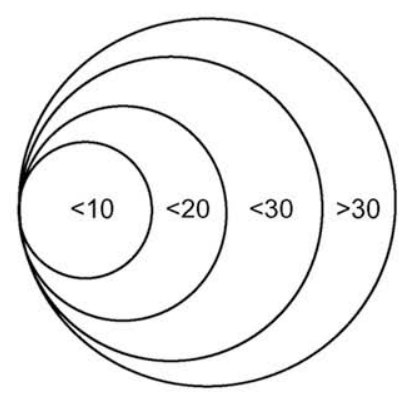

Fig. 2. Distribution of model applications among principal vegetation types.

\section{Gash original versus Gash sparse}

Some interesting trends can be drawn out from a comparison between Gash original and sparse model applications. As might be expected, the Gash sparse model gives better results than the original version in terms of modelling error, and more than $76 \%$ of the model applications resulted in errors below $10 \%$, with an important contribution of model performances with errors under $5 \%$ ( $51 \%$ of the applications), whereas for the Gash original model the figure was $27 \%$. As stated above, the latter model has a marked number of applications with errors higher than $30 \%$ (23\% of cases).

Gash models had only $32 \%$ and $26 \%$ (original and sparse versions, respectively) of validated applications. For these applications the number of very good performances (below $5 \%$ ) was higher for the sparse version ( 5 and 2 applications, respectively). The numbers of applications with results at the other levels of goodness are similar for both models (Fig. 3 ).

The better performance of the Gash sparse model may be due to the conceptual changes introduced in this version, but may also be caused by many of the applications not being duly validated, particularly those with the best results. It should also be mentioned that the original version has mainly been applied to temperate climates, whereas the sparse version has been applied mainly to tropical climates, also with good results. It is important to highlight the high number of Gash sparse model applications in semi-arid climates - a consequence of the sparse vegetation characteristic of this climate.

\section{Discussion and conclusions}

Comparison of the models that takes into account their structure and functioning was possible, but the decision as to which model is most suited to each situation must still be a decision for the modeller. The first part of this study provides theoretical information about the models that may help decide on which model to use for a specific data set and gives an overview of the models' characteristics. The second part summarizes the experiences of the models' performance and poses some interesting questions for debate.

The main and most obvious point is that several models are used very little, or in other words, three models dominate, which suggests their greater success than the other models. So, what are the causes of the limited use of certain models? Why have some simple models (e.g. the Mulder model) been abandoned? Is the Gash model fashionable and if so, why? Will the measurements' availability continue to be the most important limit for model application?

We believe that the limited use of certain models is either due to their parameter requirements (e.g. Calder two-layer model), which are not commonly or easily obtained, or to the techniques for obtaining the parameters being unusual. Moreover, if many parameters are needed to satisfy a more exhaustive description of the interception process, these are usually empirical and 

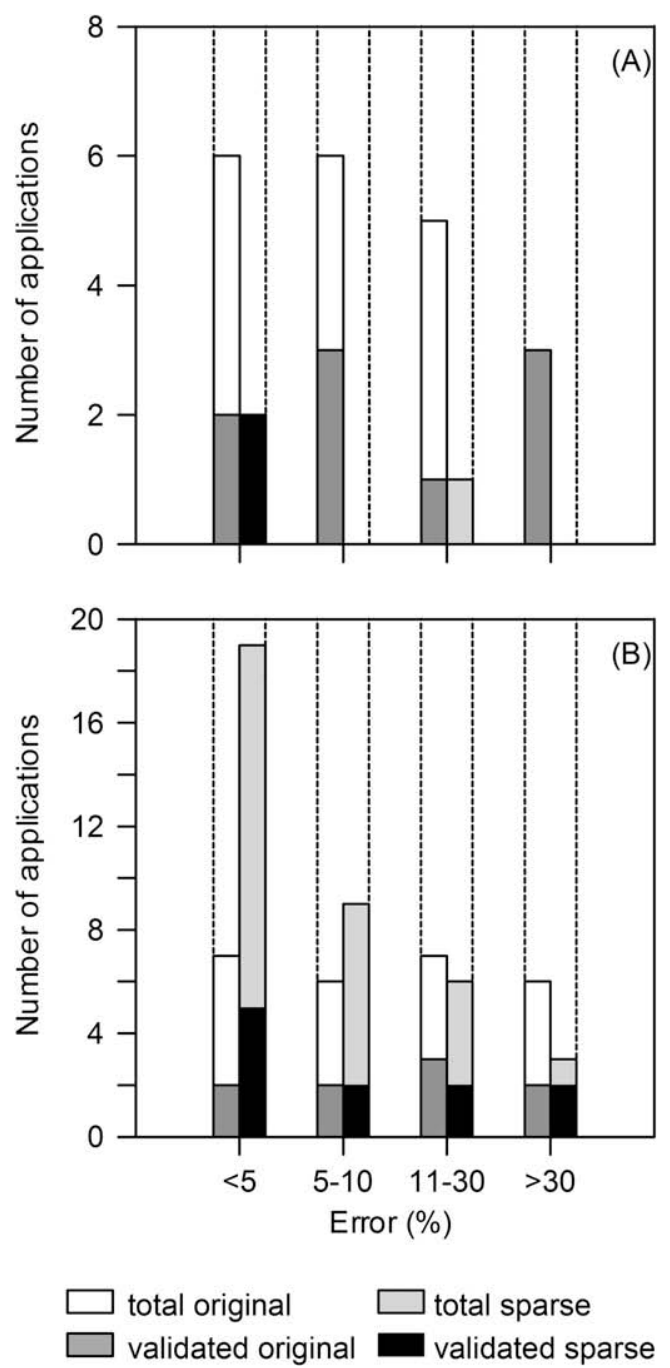

Fig. 3. Errors obtained in Rutter(A) model and Gash (B) model applications.

site-specific. Other limits for model application are that the model was only published recently (e.g. the Zeng model), or the specific vegetation type for which the model is developed (the van Dijk and Brujinzeel model). However, the main factor influencing the decision on model use is its ease of use, e.g. the workload and the costs, in terms of parameter requirements, data input, low conceptual and programming complexity - the Gash models have all these. This may be why the Gash sparse model was used so often.

One way to overcome the problem of the limited use of certain models would be to develop a user-friendly software package for the more computationally demanding models or for models that require higher programming skills. Such a facility would increase their distribution among the scientific community. A high number of published applications encourages re-use of a model and comparison with new data. This in turn provides more information about possible drawbacks of the model and aspects which need improvement. The application of new models, however well described they are and however good their results, is always more difficult when there is little information available.

In practical terms, the lack of data with high temporal definition and the great number of parameter requirements prevent the general use of most of the models reviewed. Although an accurate description of the interception process at a point scale for monitored plots is possible and may be efficient, the extrapolation of results for large areas involves significant errors, particularly if the

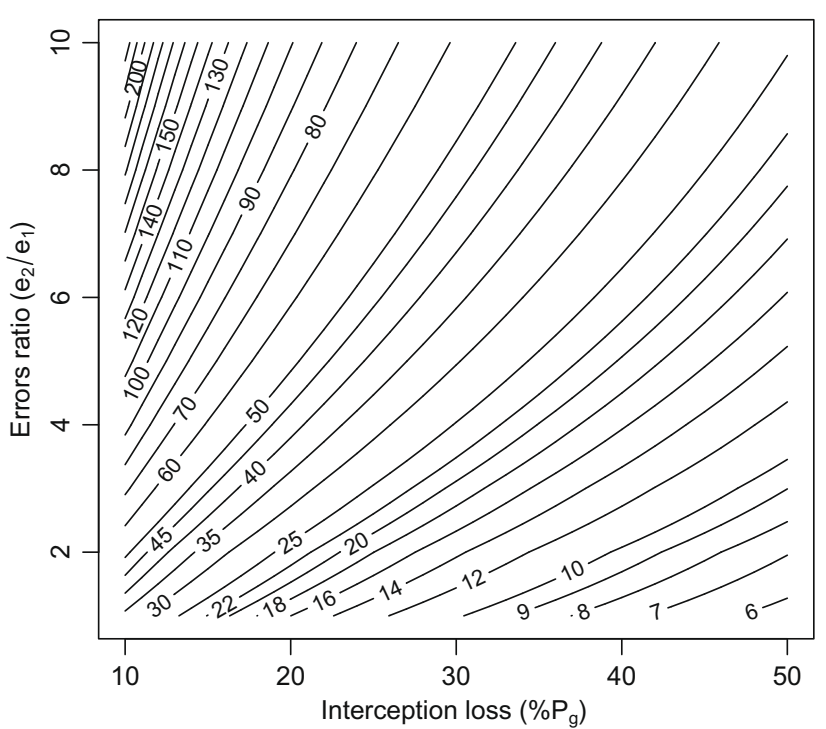

Fig. 4. Total percentage error in measured interception loss as a function of e2/e1, the ratio between error in measurements of throughfall (e2) and gross rainfall (e1), and measured interception loss (given as percentage of gross rainfall \%Pg).This graph was made assuming a measurement error in Pg of $2.5 \%$ (e1=0.025), neglecting stemflow and considering that gross rainfall and throughfall are independent measured variables. Total percentage error in measured interception loss can then be calculated as $\frac{e_{1} \sqrt{1+(1-\% P g)^{2} \times\left(e_{2} / e_{1}\right)^{2}}}{\% g g}$.

physical parameters that control the interception at a single location are assumed constant in space (Eltahir and Bras, 1993) and no rainfall variability is included. This difficulty appears as a need for subgrid parameterization of heterogeneous processes in General Circulation Models (GCM). The rainfall distribution must be spatially distributed to avoid the GCM unrealistically spreading any rainfall over the whole grid square to give low rainfall over the whole square rather than the patterns of storms which occur in reality (see Dolman and Gregory, 1987; Eltahir and Bras, 1993; Eltahir and Bras, 1994; Wang et al., 2007). Failure to account for the sub-grid variation of rainfall rate results in overestimation of interception loss. Modelling rainfall interception over large areas whilst taking into account both the physical nature of the process and the spatial variability of vegetation cover and climate, without significant simplifications and uncertainties of measurements, remains a problem. Nevertheless, interception models, especially the Rutter and Gash models, have been recently used as interception subroutines in more complex hydrological models (e.g. Finch, 1998; Ewen et al., 2000; van der Salm et al., 2007) and nearly all GCM SVAT models now use some sort of interception model that is conceptually similar to the Rutter model.

The search for new approaches to modelling increases the understanding of the process and should allow new models to include more detailed processes such as the vertical and spatial variability of interception loss at a point scale (e.g. Bassette and Bussière, 2005; Kozak et al., 2007; Liu and Liu, 2008). There are also new approaches whose objective is to simplify the modelling of this process while keeping some conceptual background. Groen and Savenije (2006) is an example of this last approach. They disregard the short temporal scale of data and propose an analytical equation for monthly interception loss estimation, which may be a very useful tool in catchment studies. Another example is that of Wang et al. (2007), who attempted to describe and estimate global interception loss by using a sub-grid of rainfall and canopystorage variability. Although it was possible to validate the model with published data on field measurements of interception loss for different locations over the world, it was difficult to obtain good results for tropical and extra-tropical areas together. 
The applications encountered in this review show the need for more vegetation-type testing. Deciduous and mixed forests require more studies, given their importance in middle latitudes and seasonal change; and the recent work by Herbst et al. (2008) which has shown the counter-intuitive result that the seasonal change in their canopy characteristics might affect interception loss less than expected. More effort to model the interception process in very sparse forests and isolated trees should also be made. In this type of vegetation, not only should the influence of rainfall incident angle and the spatial variability of throughfall be taken into account (Xiao et al., 2000; David et al., 2005), but the usual methodology of calculating the evaporation rate during wet canopy conditions (the Penman-Monteith equation) should be re-evaluated. Recent work by Pereira et al. (2009a,b), has shown the potential for a simple Dalton equation (Dalton, 1802) and tree-based approach to modelling very sparse forests. It remains an open question as to when the use of one-dimensional models like the Penman-Monteith equation is no longer valid in these conditions and what is the effect of forest sparseness on the enhancement of turbulence and evaporation. In other words, we need to evaluate the limit of the assumption in sparse models that the overall evaporation reduces linearly in proportion to the canopy cover.

One of the reasons for the few studies of shrubs and crops is that evaporation from wet canopies is clearly a net water loss for forests, but not so for short vegetation (David et al., 2005). Shrubs also gained little attention, perhaps due to the difficulty of water flow measurement techniques (Dunkerley, 2000). However, the existing studies of this type of vegetation show that, despite the structural differences between shrubs and forest, interception models can be applied in shrubs with equal success (Domingo et al., 1998).

The recent work by Murakami $(2006,2007)$ raises the intriguing idea that evaporation from splash droplets is a missing process in interception modelling. This omission would be particularly problematic in tropical areas with intensive storms and high rainfall rates. More studies on this subject are needed.

A further unresolved issue is the question of enhanced evaporation of intercepted rainfall close to coasts. Here, according to van Dijk and Bruijnzeel (2001b), the one-dimensional Penman-
Monteith equation may fail due to advection of warm maritime air. This implies horizontal temperature gradients, which to our knowledge have not been observed at the same time as the other necessary measurements. More comprehensive data are needed to establish whether the Penman-Monteith equation fails under these circumstances, or whether the high rates of interception sometimes observed at coastal sites have another explanation (e.g.Bruijnzeel and Wiersum, 1987; Dykes, 1997).

The present review also reveals some of the drawbacks to model applications: inadequate validation of the models, the few comparative studies and the uncertainties of measurements and parameter variability are the main problems. The validation of the model should be the prime point in a model assessment, as it provides objective information about the model's performance. However, this is not done or not mentioned in many of the reviewed papers. This lack impedes evaluation of the models' application. The reliability of non-validated models is low and their results are not easily comparable with validated models. Comparative studies would also enrich the modelling exercise, especially when two different approaches are compared. This study found fewer examples of this kind of paper than expected (under 20\%).

Finally, the uncertainties in model input data and parameter values are rarely taken into account during interception modelling. They should be, as they may provide insights into the quality of the model's performance and be useful in the model's result interpretation.

\section{Acknowledgements}

This study was supported by the Project Probase CGL2006$11619 / \mathrm{HID}$, set up by the Spanish Ministry of Science and Innovation (MCI), and by the GRICES/CSIC agreement (2005PT0044). The first author benefited from a pre-doctoral FPU grant MCI. The authors would also like to acknowledge the helpful comments made by the anonymous reviewers.

\section{Appendix}

Table 4.

Table 4

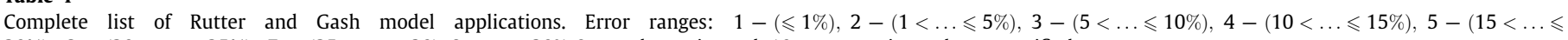
$20 \%), 6-(20<\ldots \leqslant 25 \%), 7-(25<\ldots \leqslant 30), 8$ - over $30 \%, 9$ - under-estimated, 10 - over-estimated, -unspecified.

\begin{tabular}{|c|c|c|c|c|c|c|c|}
\hline Author & Model & $\begin{array}{l}\text { Period of } \\
\text { study }\end{array}$ & Climate & $\begin{array}{l}\text { Error } \\
\text { range }\end{array}$ & Evaporation rate method & $\begin{array}{l}\text { Calibration } \\
\text { validation }\end{array}$ & Species \\
\hline \multirow[t]{2}{*}{ Aboal et al. (1999) } & Rutter & $\begin{array}{l}\leqslant 12 \\
\text { Months }\end{array}$ & Mediterranean & - & Penman-Monteith & No & Laurel forest \\
\hline & Gash & $\begin{array}{l}\leqslant 12 \\
\text { Months }\end{array}$ & Mediterranean & 2 & Penman-Monteith & No & Laurel forest \\
\hline \multirow[t]{6}{*}{ Asdak et al. (1998) } & Rutter & $\begin{array}{l}\leqslant 12 \\
\text { Months }\end{array}$ & $\begin{array}{l}\text { Tropical } \\
\text { monsoon }\end{array}$ & 3 & Penman-Monteith & No & Logged tropical forest \\
\hline & Rutter & $\begin{array}{l}\leqslant 12 \\
\text { Months }\end{array}$ & $\begin{array}{l}\text { Tropical } \\
\text { monsoon }\end{array}$ & 3 & Penman-Monteith & No & Unlogged tropical forest \\
\hline & Gash & $\begin{array}{l}\leqslant 12 \\
\text { Months }\end{array}$ & $\begin{array}{l}\text { Tropical } \\
\text { monsoon }\end{array}$ & 8 & Penman-Monteith & No & Logged tropical fores \\
\hline & Gash & $\begin{array}{l}\leqslant 12 \\
\text { Months }\end{array}$ & $\begin{array}{l}\text { Tropical } \\
\text { monsoon }\end{array}$ & 3 & Penman-Monteith & No & Unlogged tropical forest \\
\hline & $\begin{array}{l}\text { Gash } \\
\text { sparse }\end{array}$ & $\begin{array}{l}\leqslant 12 \\
\text { Months }\end{array}$ & $\begin{array}{l}\text { Tropical } \\
\text { monsoon }\end{array}$ & 3 & Penman-Monteith & No & Logged tropical fores \\
\hline & $\begin{array}{l}\text { Gash } \\
\text { sparse }\end{array}$ & $\begin{array}{l}\leqslant 12 \\
\text { Months }\end{array}$ & $\begin{array}{l}\text { Tropical } \\
\text { monsoon }\end{array}$ & 3 & Penman-Monteith & No & Unlogged tropical forest \\
\hline \multirow[t]{3}{*}{ Bigelow (2001) } & $\begin{array}{l}\text { Rutter } \\
\text { sparse }\end{array}$ & $\begin{array}{l}\leqslant 12 \\
\text { Months }\end{array}$ & $\begin{array}{l}\text { Tropical wet } \\
\text { and dry }\end{array}$ & 9 & Penman-Monteith & No & Cedrela odorata \\
\hline & $\begin{array}{l}\text { Rutter } \\
\text { sparse }\end{array}$ & $\begin{array}{l}\leqslant 12 \\
\text { Months }\end{array}$ & $\begin{array}{l}\text { Tropical wet } \\
\text { and dry }\end{array}$ & 9 & Penman-Monteith & No & Cordia alliodora \\
\hline & $\begin{array}{l}\text { Rutter } \\
\text { sparse }\end{array}$ & $\begin{array}{l}\leqslant 12 \\
\text { Months }\end{array}$ & $\begin{array}{l}\text { Tropical wet } \\
\text { and dry }\end{array}$ & 9 & Penman-Monteith & No & $\begin{array}{l}\text { Hyeronima alchorneoides } \\
\text { (continued on next page) }\end{array}$ \\
\hline
\end{tabular}


Table 4 (continued)

\begin{tabular}{|c|c|c|c|c|c|c|c|}
\hline Author & Model & $\begin{array}{l}\text { Period of } \\
\text { study }\end{array}$ & Climate & $\begin{array}{l}\text { Error } \\
\text { range }\end{array}$ & Evaporation rate method & $\begin{array}{l}\text { Calibration } \\
\text { validation }\end{array}$ & Species \\
\hline $\begin{array}{l}\text { Bringfelt and Lindroth } \\
\text { (1987) }\end{array}$ & Rutter & $>1$ Year & Continental & 8 & Penman-Monteith & Yes & Pinus sylvestris \\
\hline \multirow[t]{5}{*}{ Bryant et al. (2005) } & $\begin{array}{l}\text { Gash } \\
\text { sparse }\end{array}$ & $>1$ Year & $\begin{array}{l}\text { Humid } \\
\text { subtropical }\end{array}$ & 1 & Penman-Monteith & No & $\begin{array}{l}\text { Pinus taeda and Pinus } \\
\text { echinata }\end{array}$ \\
\hline & $\begin{array}{l}\text { Gash } \\
\text { sparse }\end{array}$ & $>1$ Year & $\begin{array}{l}\text { Humid } \\
\text { subtropical }\end{array}$ & 3 & Penman-Monteith & No & Pinus palustris \\
\hline & $\begin{array}{l}\text { Gash } \\
\text { sparse }\end{array}$ & $>1$ Year & $\begin{array}{l}\text { Humid } \\
\text { subtropical }\end{array}$ & 2 & Penman-Monteith & No & Mixed hardwood \\
\hline & $\begin{array}{l}\text { Gash } \\
\text { sparse }\end{array}$ & $>1$ Year & $\begin{array}{l}\text { Humid } \\
\text { subtropical }\end{array}$ & 2 & Penman-Monteith & No & Quercus berberidifolia \\
\hline & $\begin{array}{l}\text { Gash } \\
\text { sparse }\end{array}$ & $>1$ Year & $\begin{array}{l}\text { Humid } \\
\text { subtropical }\end{array}$ & 3 & Penman-Monteith & No & $\begin{array}{l}\text { Quercus alba, P. echinata } \\
\text { P.palustris }\end{array}$ \\
\hline Calder et al. (1986) & Rutter & $>1$ Year & $\begin{array}{l}\text { Tropical } \\
\text { monsoon }\end{array}$ & - & Penman-Monteith & No & Rainforest \\
\hline \multirow[t]{2}{*}{$\begin{array}{l}\text { Carlyle-Moses and } \\
\text { Price (1999) }\end{array}$} & Gash & $\leqslant 6$ Months & Continental & 4 & Empirical regression & No & $\begin{array}{l}\text { Quercus rubra and Acer } \\
\text { saccharum }\end{array}$ \\
\hline & $\begin{array}{l}\text { Gash } \\
\text { sparse }\end{array}$ & $\leqslant 6$ Months & Continental & 2 & Empirical regression & No & $\begin{array}{l}\text { Quercus rubra and Acer } \\
\text { saccharum }\end{array}$ \\
\hline $\begin{array}{l}\text { Carlyle-Moses and } \\
\text { Price (2007) }\end{array}$ & $\begin{array}{l}\text { Gash } \\
\text { sparse }\end{array}$ & $>1$ Year & Temperate & 8 & Empirical regression & No & $\begin{array}{l}\text { Pinus pseudostrobus, } \\
\text { Q.canbyi, Q.laeta }\end{array}$ \\
\hline \multirow[t]{2}{*}{ Cuartas et al. (2007) } & $\begin{array}{l}\text { Gash } \\
\text { sparse }\end{array}$ & $>1$ Year & $\begin{array}{l}\text { Tropical } \\
\text { monsoon }\end{array}$ & 5 & Penman-Monteith & No & Rainforest \\
\hline & Rutter & $>1$ Year & $\begin{array}{l}\text { Tropical } \\
\text { monsoon }\end{array}$ & 9 & Penman-Monteith & No & Rainforest \\
\hline Deguchi et al. (2006) & $\begin{array}{l}\text { Gash } \\
\text { sparse }\end{array}$ & $>1$ Year & $\begin{array}{l}\text { Humid } \\
\text { subtropical }\end{array}$ & 2 & Empirical regression & No & Quercus serrata \\
\hline \multirow[t]{2}{*}{$\begin{array}{l}\text { van Dijk and } \\
\text { Bruijnzeel (2001b) }\end{array}$} & $\begin{array}{l}\text { Gash } \\
\text { sparse }\end{array}$ & $\leqslant 6$ Months & $\begin{array}{l}\text { Tropical } \\
\text { rainforest }\end{array}$ & 3 & $\begin{array}{l}\text { Empirical regression and } \\
\text { optimization }\end{array}$ & No & Agrosystem \\
\hline & $\begin{array}{l}\text { Gash } \\
\text { sparse }\end{array}$ & $\begin{array}{l}\leqslant 12 \\
\text { Months }\end{array}$ & $\begin{array}{l}\text { Tropical } \\
\text { rainforest }\end{array}$ & 1 & Empirical regression & No & Agrosystem \\
\hline Dolman (1987) & Gash & $>1$ Year & Temperate & 3 & Empirical regression & No & Quercus rubra \\
\hline \multirow[t]{2}{*}{ Domingo et al. (1998) } & Rutter & $\begin{array}{l}\leqslant 12 \\
\text { Months }\end{array}$ & Semi-arid & - & Penman-Monteith & Yes & Anthylis cytisoides \\
\hline & Rutter & $\begin{array}{l}\leqslant 12 \\
\text { Months }\end{array}$ & Semi-arid & - & Penman-Monteith & Yes & Retama sphaerocarpa \\
\hline Dykes (1997) & $\begin{array}{l}\text { Gash } \\
\text { sparse }\end{array}$ & $\leqslant 6$ Months & $\begin{array}{l}\text { Tropical } \\
\text { rainforest }\end{array}$ & 1 & Empirical regression & No & Various evergreen species \\
\hline $\begin{array}{l}\text { Gash and Morton } \\
\text { (1978) }\end{array}$ & Rutter & $>1$ Year & Temperate & 3 & Penman-Monteith & Yes & Pinus sylvestris \\
\hline Gash (1979) & Gash & $>1$ Year & Temperate & 2 & Penman-Monteith & No & Pinus sylvestris \\
\hline \multirow[t]{2}{*}{ Gash et al. (1980) } & Rutter & $>1$ Year & Temperate & 5 & Penman-Monteith & Yes & $\begin{array}{l}\text { Picea sitchensis, Pinus } \\
\text { sylvestris }\end{array}$ \\
\hline & Gash & $>1$ Year & Temperate & 5 & Penman-Monteith & Yes & $\begin{array}{l}\text { Picea sitchensis, Pinus } \\
\text { sylvestris }\end{array}$ \\
\hline \multirow[t]{2}{*}{ Gash et al. (1995) } & Gash & $\begin{array}{l}\leqslant 12 \\
\text { Months }\end{array}$ & Temperate & 8 & Penman-Monteith & No & Pinus pinaster \\
\hline & $\begin{array}{l}\text { Gash } \\
\text { sparse }\end{array}$ & $\begin{array}{l}\leqslant 12 \\
\text { months }\end{array}$ & Temperate & - & Penman-Monteith & No & Pinus pinaster \\
\hline \multirow[t]{2}{*}{ Gash et al. (1999) } & Rutter & $\leqslant 1$ Month & Mediterranean & 7 & Penman-Monteith & No & Pinus pinaster \\
\hline & $\begin{array}{l}\text { Rutter } \\
\text { sparse }\end{array}$ & $\leqslant 1$ Month & Mediterranean & 4 & Penman-Monteith & No & Pinus pinaster \\
\hline Germer et al. (2006) & $\begin{array}{l}\text { Gash } \\
\text { sparse }\end{array}$ & $\leqslant 6$ Months & $\begin{array}{l}\text { Tropical wet } \\
\text { and dry }\end{array}$ & - & Not specified & No & Rainforest \\
\hline Hall et al. (1996) & Rutter & $\leqslant 6$ Months & $\begin{array}{l}\text { Tropical } \\
\text { rainforest }\end{array}$ & 2 & Penman-Monteith & No & Rainforest \\
\hline Herbst et al. (2006) & Gash & $>1$ Year & Temperate & 4 & Penman-Monteith & Yes & Hedgerows \\
\hline Holscher et al. (2004) & Gash & $\begin{array}{l}\leqslant 12 \\
\text { Months }\end{array}$ & $\begin{array}{l}\text { Tropical } \\
\text { rainforest }\end{array}$ & 4 & Empirical regression & No & Various evergreen species \\
\hline Hormann et al. (1996) & Gash & $>1$ Year & $\begin{array}{l}\text { Maritime } \\
\text { temperate }\end{array}$ & 8 & Other & No & Fagus sylvatica \\
\hline Hutjes et al. (1990) & Gash & $\leqslant 6$ Months & $\begin{array}{l}\text { Tropical } \\
\text { rainforest }\end{array}$ & 8 & $\begin{array}{l}\text { Penman-Monteith and } \\
\text { regression }\end{array}$ & No & Various evergreen species \\
\hline \multirow[t]{2}{*}{ Jackson (2000) } & $\begin{array}{l}\text { Gash } \\
\text { sparse }\end{array}$ & $>1$ Year & Semi-arid & 2 & Penman-Monteith & No & Agroforestry system \\
\hline & $\begin{array}{l}\text { Gash } \\
\text { sparse }\end{array}$ & $>1$ Year & Semi-arid & 2 & Penman-Monteith & No & Agroforestry system \\
\hline \multirow[t]{2}{*}{ Jetten (1996) } & Rutter & $\leqslant 6$ Months & $\begin{array}{l}\text { Tropical } \\
\text { rainforest }\end{array}$ & 4 & Penman-Monteith & No & Evergreen forest \\
\hline & Rutter & $\leqslant 6$ Months & $\begin{array}{l}\text { Tropical } \\
\text { rainforest }\end{array}$ & 4 & Penman-Monteith & No & Mixed forest \\
\hline $\begin{array}{l}\text { Lankreijer et al. } \\
\text { (1993) }\end{array}$ & Gash & $\leqslant 6$ Months & Temperate & 4 & $\begin{array}{l}\text { Penman-Monteith and } \\
\text { regression }\end{array}$ & No & Quercus rubra \\
\hline $\begin{array}{l}\text { Lankreijer et al. } \\
\text { (1993) }\end{array}$ & Gash & $\begin{array}{l}\leqslant 12 \\
\text { Months }\end{array}$ & Temperate & 2 & $\begin{array}{l}\text { Penman-Monteith and } \\
\text { regression }\end{array}$ & No & Pinus pinaster \\
\hline
\end{tabular}


Table 4 (continued)

\begin{tabular}{|c|c|c|c|c|c|c|c|}
\hline Author & Model & $\begin{array}{l}\text { Period of } \\
\text { study }\end{array}$ & Climate & $\begin{array}{l}\text { Error } \\
\text { range }\end{array}$ & Evaporation rate method & $\begin{array}{l}\text { Calibration } \\
\text { validation }\end{array}$ & Species \\
\hline \multirow[t]{2}{*}{$\begin{array}{l}\text { Lankreijer et al. } \\
\text { (1999) }\end{array}$} & $\begin{array}{l}\text { Gash } \\
\text { sparse }\end{array}$ & $\leqslant 3$ Months & $\begin{array}{l}\text { Continental } \\
\text { subarctic }\end{array}$ & 10 & Penman-Monteith & No & Sparse mixed forest \\
\hline & Gash & $\leqslant 3$ Months & $\begin{array}{l}\text { Continental } \\
\text { subarctic }\end{array}$ & 10 & Penman-Monteith & No & Closed mixed forest \\
\hline Link et al. (2004) & $\begin{array}{l}\text { Gash } \\
\text { sparse }\end{array}$ & $>1$ Year & $\begin{array}{l}\text { Maritime } \\
\text { temperate }\end{array}$ & 2 & $\begin{array}{l}\text { Penman-Monteith and } \\
\text { regression }\end{array}$ & Yes & $\begin{array}{l}\text { Pseudotsuga menziesii Tsuga } \\
\text { heterophylla } \\
\text { Thuja plicata }\end{array}$ \\
\hline Llorens (1997) & Gash & $>1$ Year & Mediterranean & 3 & $\begin{array}{l}\text { Penman-Monteith and } \\
\text { regression }\end{array}$ & Yes & Pinus sylvestris \\
\hline \multirow[t]{2}{*}{ Lloyd et al. (1988) } & Rutter & $>1$ Year & $\begin{array}{l}\text { Tropical } \\
\text { rainforest }\end{array}$ & 2 & Penman-Monteith & Yes & Rainforest \\
\hline & Gash & $>1$ Year & $\begin{array}{l}\text { Tropical } \\
\text { rainforest }\end{array}$ & 2 & Penman-Monteith & Yes & Rainforest \\
\hline Loescher et al. (2005) & Rutter & $>1$ Year & $\begin{array}{l}\text { Tropical } \\
\text { rainforest }\end{array}$ & - & Penman-Monteith & No & Rainforest \\
\hline Loustau et al. (1992) & Gash & $>1$ Year & Temperate & 3 & $\begin{array}{l}\text { Penman-Monteith and } \\
\text { regression }\end{array}$ & No & Pinus pinaster \\
\hline Murakami (2007) & $\begin{array}{l}\text { Gash } \\
\text { sparse }\end{array}$ & $>1$ Year & $\begin{array}{l}\text { Maritime } \\
\text { temperate }\end{array}$ & 1 & Empirical regression & No & Japanese cypreses \\
\hline $\begin{array}{l}\text { Navar and Bryan } \\
\text { (1994) }\end{array}$ & Gash & $\leqslant 6$ Months & Semi-arid & 1 & Empirical regression & No & Shrubs \\
\hline \multirow[t]{6}{*}{ Navar et al. (1999b) } & $\begin{array}{l}\text { Gash } \\
\text { sparse }\end{array}$ & $>1$ Year & Semi-arid & 3 & Empirical regression & Yes & Shrubs \\
\hline & $\begin{array}{l}\text { Gash } \\
\text { sparse }\end{array}$ & $>1$ Year & Semi-arid & 4 & Empirical regression & Yes & Shrubs \\
\hline & $\begin{array}{l}\text { Gash } \\
\text { sparse }\end{array}$ & $>1$ Year & Semi-arid & 8 & Empirical regression & Yes & Shrubs \\
\hline & $\begin{array}{l}\text { Gash } \\
\text { sparse }\end{array}$ & $>1$ Year & Semi-arid & 8 & Empirical regression & Yes & Shrubs \\
\hline & $\begin{array}{l}\text { Gash } \\
\text { sparse }\end{array}$ & $>1$ Year & Semi-arid & 5 & Empirical regression & Yes & Shrubs \\
\hline & $\begin{array}{l}\text { Gash } \\
\text { sparse }\end{array}$ & $>1$ Year & Semi-arid & 1 & Empirical regression & Yes & Shrubs \\
\hline Navar et al. (1999a) & $\begin{array}{l}\text { Gash } \\
\text { sparse }\end{array}$ & $>1$ Year & Semi-arid & 1 & Empirical regression & Yes & Shrubs \\
\hline $\begin{array}{l}\text { Pearce and Rowe } \\
\text { (1981) }\end{array}$ & Gash & $>1$ Year & Temperate & 3 & Empirical regression & No & Various evergreen species \\
\hline \multirow[t]{2}{*}{ Pearce et al. (1980) } & Rutter & $>1$ Year & Temperate & 3 & Penman-Monteith & Yes & Pinus sylvestris \\
\hline & Gash & $>1$ Year & Temperate & 2 & Penman-Monteith & Yes & Pinus sylvestris \\
\hline $\begin{array}{l}\text { Price and Carlyle- } \\
\text { Moses (2003) }\end{array}$ & $\begin{array}{l}\text { Gash } \\
\text { sparse }\end{array}$ & $\leqslant 6$ Months & Continental & 4 & Penman-Monteith & No & $\begin{array}{l}\text { Quercus rubra, Acer } \\
\text { saccharum }\end{array}$ \\
\hline Pypker et al. (2005) & Gash & $\leqslant 6$ Months & $\begin{array}{l}\text { Maritime } \\
\text { temperate }\end{array}$ & 2 & Empirical regression & No & Pseudotsuga menziesii \\
\hline Rao (1987) & Gash & $>1$ Year & $\begin{array}{l}\text { Tropical } \\
\text { monsoon }\end{array}$ & 3 & Penman-Monteith & No & Cashew trees \\
\hline Rowe (1983) & Gash & $>1$ Year & Temperate & 3 & Empirical regression & Yes & Nothofagus spp. \\
\hline Rutter et al. (1971) & Rutter & $>1$ Year & Temperate & - & Penman-Monteith & No & Pinus nigra \\
\hline \multirow[t]{5}{*}{ Rutter et al. (1975) } & Rutter & $>1$ Year & Temperate & 3 & Penman-Monteith & No & Pinus nigra \\
\hline & Rutter & $>1$ Year & Temperate & 2 & Penman-Monteith & No & Pseudotsuga menzesii \\
\hline & Rutter & $>1$ Year & Temperate & 2 & Penman-Monteith & No & Picea abies \\
\hline & Rutter & $>1$ Year & Temperate & 1 & Penman-Monteith & No & Carpinus betulus \\
\hline & Rutter & $>1$ Year & Temperate & 5 & Penman-Monteith & No & Quercus robur \\
\hline \multirow{2}{*}{$\begin{array}{l}\text { Schellekens et al. } \\
\text { (1999) }\end{array}$} & Rutter & $\leqslant 3$ Months & Tropical & 9 & Penman-Monteith & No & Tabonuco type forest \\
\hline & Gash & $\leqslant 3$ Months & Tropical & 9 & Penman-Monteith & No & Tabonuco type forest \\
\hline Schellekens (2000) & Rutter & $\leqslant 3$ Months & Tropical & - & Penman-Monteith & No & Tabonuco type forest \\
\hline \multirow[t]{2}{*}{ Sraj et al. (2008) } & $\begin{array}{l}\text { Gash } \\
\text { sparse }\end{array}$ & $\leqslant 12$ Months & Mediterranean & 3 & Empirical regression & No & Decidous mixed forest \\
\hline & $\begin{array}{l}\text { Gash } \\
\text { sparse }\end{array}$ & $\leqslant 12$ Months & Mediterranean & 2 & Empirical regression & No & Decidous mixed forest \\
\hline Tallaksen et al. (1996) & Rutter & $>1$ Year & $\begin{array}{l}\text { Continental } \\
\text { subarctic }\end{array}$ & 3 & Penman-Monteith & Yes & Picea abies \\
\hline Tani et. al. (2003) & Rutter & $>1$ Year & $\begin{array}{l}\text { Tropical } \\
\text { rainforest }\end{array}$ & - & Penman-Monteith & No & Rainforest \\
\hline \multirow[t]{5}{*}{ Valente et al. (1997) } & $\begin{array}{l}\text { Gash } \\
\text { sparse }\end{array}$ & $>1$ Year & Mediterranean & 2 & Penman-Monteith & Yes & Eucalyptus globulus \\
\hline & $\begin{array}{l}\text { Gash } \\
\text { sparse }\end{array}$ & $>1$ Year & Mediterranean & 2 & Penman-Monteith & Yes & Pinus pinaster \\
\hline & $\begin{array}{l}\text { Rutter } \\
\text { sparse }\end{array}$ & $>1$ Year & Mediterranean & 2 & Penman-Monteith & Yes & Eucalyptus globulus \\
\hline & $\begin{array}{l}\text { Rutter } \\
\text { sparse }\end{array}$ & $>1$ Year & Mediterranean & 2 & Penman-Monteith & Yes & Pinus pinaster \\
\hline & Gash & $>1$ Year & Mediterranean & 8 & Penman-Monteith & Yes & $\begin{array}{l}\text { Eucalyptus globulus } \\
\quad \text { (continued on next page) }\end{array}$ \\
\hline
\end{tabular}


Table 4 (continued)

\begin{tabular}{|c|c|c|c|c|c|c|c|}
\hline Author & Model & $\begin{array}{l}\text { Period of } \\
\text { study }\end{array}$ & Climate & $\begin{array}{l}\text { Error } \\
\text { range }\end{array}$ & Evaporation rate method & $\begin{array}{l}\text { Calibration } \\
\text { validation }\end{array}$ & Species \\
\hline & Gash & $>1$ Year & Mediterranean & 8 & Penman-Monteith & Yes & Pinus pinaster \\
\hline & Rutter & $>1$ Year & Mediterranean & 8 & Penman-Monteith & Yes & Eucalyptus globulus \\
\hline & Rutter & $>1$ Year & Mediterranean & 8 & Penman-Monteith & Yes & Pinus pinaster \\
\hline $\begin{array}{l}\text { Wallace and } \\
\text { McJannet (2006) }\end{array}$ & $\begin{array}{l}\text { Gash } \\
\text { sparse }\end{array}$ & $>1$ Year & $\begin{array}{l}\text { Tropical } \\
\text { rainforest }\end{array}$ & 3 & Penman-Monteith & No & Rainforest \\
\hline \multirow[t]{6}{*}{$\begin{array}{l}\text { Wallace and } \\
\text { McJannet (2008) }\end{array}$} & $\begin{array}{l}\text { Gash } \\
\text { sparse }\end{array}$ & $>1$ Year & $\begin{array}{l}\text { Tropical } \\
\text { rainforest }\end{array}$ & 2 & $\begin{array}{l}\text { Penman-Monteith, regression } \\
\text { and optimization }\end{array}$ & No & Rainforest \\
\hline & $\begin{array}{l}\text { Gash } \\
\text { sparse }\end{array}$ & $>1$ Year & $\begin{array}{l}\text { Tropical } \\
\text { rainforest }\end{array}$ & 2 & $\begin{array}{l}\text { Penman-Monteith, regression } \\
\text { and optimization }\end{array}$ & No & Rainforest \\
\hline & $\begin{array}{l}\text { Gash } \\
\text { sparse }\end{array}$ & $>1$ Year & $\begin{array}{l}\text { Tropical } \\
\text { rainforest }\end{array}$ & 3 & $\begin{array}{l}\text { Penman-Monteith, regression } \\
\text { and optimization }\end{array}$ & No & Rainforest \\
\hline & $\begin{array}{l}\text { Gash } \\
\text { sparse }\end{array}$ & $>1$ Year & $\begin{array}{l}\text { Tropical } \\
\text { rainforest }\end{array}$ & 3 & $\begin{array}{l}\text { Penman-Monteith, regression } \\
\text { and optimization }\end{array}$ & No & Rainforest \\
\hline & $\begin{array}{l}\text { Gash } \\
\text { sparse }\end{array}$ & $>1$ Year & $\begin{array}{l}\text { Tropical } \\
\text { rainforest }\end{array}$ & 2 & $\begin{array}{l}\text { Penman-Monteith, regression } \\
\text { and optimization }\end{array}$ & No & Rainforest \\
\hline & $\begin{array}{l}\text { Gash } \\
\text { sparse }\end{array}$ & $>1$ Year & $\begin{array}{l}\text { Tropical } \\
\text { rainforest }\end{array}$ & - & $\begin{array}{l}\text { Penman-Monteith, regression } \\
\text { and optimization }\end{array}$ & No & Rainforest \\
\hline $\begin{array}{l}\text { Whelan and } \\
\text { Anderson (1996) }\end{array}$ & Rutter & $\leqslant 3$ Months & Temperate & 2 & Penman-Monteith & Yes & Picea abies \\
\hline Whitehead and & Rutter & $>1$ Year & Temperate & - & Penman-Monteith & Yes & Unthinned Pinus radiata \\
\hline Kelliher (1991) & Rutter & $>1$ Year & Temperate & - & Penman-Monteith & Yes & Thinned Pinus radiata \\
\hline \multirow[t]{2}{*}{ Zeng et al. (2000) } & Rutter & $>1$ Year & Tropical & - & Penman-Monteith & No & Not specified \\
\hline & Rutter & $>1$ Year & Mediterranean & - & Penman-Monteith & No & Not specified \\
\hline Zhang et al. (2006) & Gash & $\leqslant 12$ Months & $\begin{array}{l}\text { Tropical } \\
\text { monsoon }\end{array}$ & 6 & $\begin{array}{l}\text { Penman-Monteith and } \\
\text { regression }\end{array}$ & Yes & $\begin{array}{l}\text { Cunninghamia Inceolata } \\
\text { Pinus masoniana }\end{array}$ \\
\hline Zhang et al. (2006) & $\begin{array}{l}\text { Gash } \\
\text { sparse }\end{array}$ & $\leqslant 12$ Months & $\begin{array}{l}\text { Tropical } \\
\text { monsoon }\end{array}$ & 3 & $\begin{array}{l}\text { Penman-Monteith and } \\
\text { regression }\end{array}$ & Yes & $\begin{array}{l}\text { Understorey of } \\
\text { Tropical forest }\end{array}$ \\
\hline
\end{tabular}

\section{References}

Aboal, J., Jimenez, M., Morales, D., Hernandez, J., 1999. Rainfall interception in laurel forest in the Canary Islands. Agricultural and Forest Meteorology 97, 73-86.

Arnell, N., 2002. Hydrology and Global Environmental Change. Pearson Education, Harlow. 346 pp.

Asdak, C., Jarvis, P., Gardingen, P., 1998. Modelling rainfall interception in unlogged and logged forest areas of Central Kalimantan, Indonesia. Hydrology and Earth System Sciences 2, 211-220.

Bassette, C., Bussière, F., 2005. 3-D modelling of the banana architecture for simulation of rainfall interception parameters. Agricultural and Forest Meteorology 129, 95-100.

Bigelow, S., 2001. Evapotranspiration modelled from stands of three broad-leaved tropical trees in Costa Rica. Hydrological Processes 15, 2779-2796.

Bringfelt, B., Lindroth, A., 1987. Synoptic evapotranspiration model applied to two northern forests of different density, Sweden. Journal of Hydrology 95, 185201

Bruijnzeel, L.A., Wiersum, K.F., 1987. Rainfall interception by a young Acacia auriculiformis (A. Cunn) plantation forest in west Java, Indonesia: application of Gash's analytical model. Hydrological Processes 1, 309-319.

Brutsaert, W., 2005. Hydrology. Cambridge University Press, New York. 605 pp.

Bryant, M., Bhata, S., Jacobs, J., 2005. Measurements and modeling of throughfall variability for five forest communities in the southeastern US. Journal of Hydrology 312, 95-108.

Bussière, F., Solmon, F., Fouèrè, A., 2002. Implementation and evaluation of drop, model for the simulation of rainfall distribution below plants described in 3D. Agronomie 22, 93-103.

Calder, I., 1977. A model of transpiration and interception loss from a spruce forest in Plynlimon, Central Wales. Journal of Hydrology 33, 247-265.

Calder, I., 1979. Do trees use more water than grass? Water services 83, 11-14.

Calder, I., 1986. A stochastic model of rainfall interception. Journal of Hydrology 89, 65-71.

Calder, I., 1990. Evaporation in the Uplands. John Wiley and Sons Inc., Chichester. 148 pp.

Calder, I., 1996. Dependence of rainfall interception on drop size: 1. Development of the two-layer stochastic model. Journal of Hydrology 185, 363-378.

Calder, I., Wright, I., Murdiyarso, D., 1986. A study of evaporation from tropical rain forest - west Java. Journal of Hydrology 89, 13-31.

Carlyle-Moses, D., Price, A., 1999. An evaluation of the Gash interception model in a northern hardwood stand. Journal of Hydrology 214, 103-110.

Carlyle-Moses, D., Price, A., 2007. Modelling canopy interception loss from a Madrean pine-oak stand, northeastern Mexico. Hydrological Processes 21, 2572-2580.

Castro, G., Romero, P., Gómez, J., Fereres, E., 2006. Rainfall redistribution beneath an olive orchard. Agricultural Water Management 86, 249-258.

Cooper, T., Lockwood, J., 1987. The influence of rainfall distribution in numerical simulation of evapotranspiration from a multilayer model pine canopy. Water Resources Research 23, 1645-1656.
Crockford, R., Richardson, D., 2000. Partitioning of rainfall into throughfall, stemflow and interception: effect of forest type, ground cover and climate. Hydrological Processes 14, 2903-2920.

Cuartas, L., Tomasella, J., Nobre, A., Hodnett, M., Waterloo, M.J., Munera, J., 2007. Interception water-partitioning dynamics for a pristine rainforest in Central Amazonia: marked differences between normal and dry years. Agricultural and Forest Meteorology 145, 69-83.

Dalton, J., 1802. On evaporation. Essay III in: Experimental essays on the constitution of mixed gases; on the force of stream or vapour from water or other liquids in different temperatures; both in a Torrecellian vacuum and in air; on evaporation; and on the expansion of gases by heat. Memoris and Proceedings of the Literory Philosophical Society Manchester 5 , 574-594.

David, J., Valente, F., Gash, J., 2005. Evaporation of intercepted rainfall. In: Anderson, M. (Ed.), Encyclopedia of Hydrological Sciences. John Wiley and Sons. Ltd.,, pp. 627-634 (Chapter 43).

Davie, T., Durocher, M., 1997. A model to consider the spatial variability of rainfall partitioning within deciduous canopy. I. Model description. Hydrological Processes 11, 1509-1523.

Deguchi, A., Hattori, S., Park, H.-T., 2006. The influence of seasonal changes in canopy structure on interception loss: application of the revised Gash model Journal of Hydrology 318, 80-102.

Dingman, S., 2002. Physical Hydrology. Prentice Hall, Upper Saddle River. 646 p.

Dolman, A., 1987. Summer and winter rainfall interception in an oak forest. Predictions with an analytical and a numerical simulation model. Journal of Hydrology 90, 1-9.

Dolman, A., Gregory, D., 1987. The parameterization of rainfall interception in GCMs. Quarterly Journal of the Royal Meteorological Society 118, $455-467$.

Domingo, F., Sanchez, G., Moro, M., Brenner, A., Puigdefabregas, J., 1998. Measurement and modelling of rainfall interception by three semi-arid canopies. Agricultural and Forest Meteorology 91, 275-292.

Dunkerley, D., 2000. Measuring interception loss and canopy storage in dryland vegetation: a brief review and evaluation of available research strategies. Hydrological Processes 14, 669-678.

Dykes, A., 1997. Rainfall interception from a lowland tropical rainforest in Brunei. Journal of Hydrology 200, 260-279.

Eltahir, E., Bras, R., 1993. A description of rainfall interception over large areas. Journal of Climate 6, 1002-1008.

Eltahir, E., Bras, R., 1994. Comments on 'The parametrization of rainfall interception in GCMs' by A.J. Dolman and D. Gregory (April 1992, 118, 455-467). Quarterly Journal of the Royal Meteorological Society 120, 733-734.

Ewen, J., Parkin, G., OConnell, P., 2000. SHETRAN: a coupled surface/subsurface modelling system for 3D water flow and sediment and solute transport in river basins. Journal of Hydrologic Engineering ASCE 5, 250-258.

Finch, J., 1998. Estimating direct groundwater recharge using a simple water balance model - sensitivity to land surface parameters. Journal of Hydrology $211,112-125$. 
Gash, J., 1979. An analytical model of rainfall interception by forest. Quarterly Journal of the Royal Meteorological Society 105, 43-55.

Gash, J., Lloyd, C., Lachaud, G., 1995. Estimating sparse forest rainfall interception with an analytical model. Journal of Hydrology 170, 79-86.

Gash, J., Morton, A., 1978. Application of the Rutter model to the estimation of the interception loss from Thetford forest. Journal of Hydrology 38, 49-58.

Gash, J., Shuttleworth, W., 2007. Evaporation. Benchmark Papers in Hydrology, vol 2. IAHS Press, Wallingford. $521 \mathrm{pp}$

Gash, J., Wright, I., Lloyd, C., 1980. Comparative estimates of interception loss from three coniferous forests in Great Britain. Journal of Hydrology 48, 89-105.

Gash, J., Valente, F., David, J., 1999. Estimates and measurements of evaporation from wet, sparse pine forest in Portugal. Agricultural and Forest Meteorology 94, 149-158.

Germer, S., Elsenbeer, H., Moraes, J., 2006. Throughfall and temporal trends of rainfall redistribution in an open tropical rainforest, south-western Amazonia, Rodônia, Brazil. Hydrology and Earth System Sciences 10, 383-393.

Groen, M.D., Savenije, H., 2006. A monthly interception equation based on the statistical characteristics of daily rainfall. Water Resources Research 42 , W12417.

Hall, R., Calder, I., Gunawardena, E., Rosier, P., 1996. Dependence of rainfall interception on drop size: 3. Implementation and comparative performance of the stochastic model using data from a tropical site in Sri Lanka. Journal of Hydrology 185, 389-407.

Herbst, M., Roberts, J., Rosier, P., Gowing, D., 2006. Measuring and modelling the rainfall interception loss by hedgerows in southern England. Agricultural and Forest Meteorology 141, 244-256.

Herbst, M., Rosier, P., McNeil, D.D., Harding, R., Gowing, D.J., 2008. Seasonal variability of interception evaporation from the canopy of a mixed deciduous forest. Agricultural and Forest Meteorology 148, 1655-1667.

Holscher, D., Kohler, L., Dijk, A.V., Bruijnzeel, L., 2004. The importance of epiphytes to total rainfall interception by a tropical montane rain forest in Costa Rica. Journal of Hydrology 292, 308-322.

Hormann, G. Branding, A., Clemen, T., Herbst, M., Hinrichs, A., Thamm, F., 1996. Calculation and simulation of wind controlled canopy interception of a beech forest in northern Germany. Agricultural and Forest Meteorology 79, 131-148.

Horton, R., 1919. Rainfall interception. Monthly Weather Review 47, 603-623.

Hutjes, R., Wierda, A., Veen, A., 1990. Rainfall interception in the Tai Forest, Ivory Coast: application of two simulation models to a humid tropical system. Journal of Hydrology 114, 259-275.

Jackson, N., 2000. Measured and modelled rainfall interception loss from an agroforestry system in Kenya. Agricultural and Forest Meteorology 100, 232-336.

Jetten, V., 1996. Interception of tropical rain forest: performance of a canopy water balance model. Hydrological Processes 10, 671-685.

Klaassen, W., Bosveld, F., de Water, E., 1998. Water storage and evaporation as constituents of rainfall interception. Journal of Hydrology, 36-50.

Kozak, J., Ahuja, L., Green, T., Ma, L., 2007. Modelling crop canopy and residue rainfall interception effects on soil hydrological components for semi-arid agriculture. Hydrological Processes 21, 229-241.

Lankreijer, H., Hendriks, M., Klaassen, W., 1993. A comparison of models simulating rainfall interception of forests. Agricultural and Forest Meteorology 64, 187-199.

Lankreijer, H., Lundberg, A., Grelle, A., Lindroth, A., Seibert, J., 1999. Evaporation and storage of intercepted rain analysed by comparing two models applied to a boreal forest. Agricultural and Forest Meteorology, 595-604.

Levia, D., Frost, E. 2003. A review and evaluation of stemflow literature in the hydrologic and biogeochemical cycles of forested and agricultural ecosystems. Journal of Hydrology 274, 1-29.

Levia, D., Frost, E., 2006. Variability of throughfall volume and solute inputs in wooded ecosystems. Progress in Physical Geography 30, 605-632.

Link, T., Unsworth, M., Marks, D., 2004. The dynamics of rainfall interception by a seasonal temperate rainforest. Agricultural and Forest Meteorology 124, 171191.

Liu, J., 1988. A theoretical model of the process of rainfall interception in forest canopy. Ecological Modelling 42, 111-123.

Liu, L., Liu, J., 2008. A rainfall interception model for inhomogeneous forest canopy. Frontiers of Forestry in China 3, 50-57.

Liu, S., 1997. A new model for the prediction of rainfall interception in forest canopies. Ecological Modelling 99, 151-159.

Liu, S., 2001. Evaluation of the Liu model for predicting rainfall interception in forests world-wide. Hydrological Processes 15, 2341-2360.

Llorens, P., 1997. Rainfall interception by a Pinus sylvestris forest patch overgrown in a Mediterranean mountainous abandoned area ii. Assessment of the applicability of Gash's analytical model. Journal of Hydrology 199, 346-359.

Llorens, P., Domingo, F., 2007. Rainfall partitioning by vegetation under mediterranean conditions. A review of studies in Europe. Journal of Hydrology 335, 37-54.

Lloyd, C., Gash, J., Shuttleworth, W., Marques, F.A., 1988. The measurement and modelling of rainfall interception by Amazonian rain forest. Agricultural and Forest Meteorology 43, 277-294.

Lockwood, J., 1990. The influence of temperature variations on interception loss and water storage in vegetation canopies. Water Resources Research 26, 941-943.

Lockwood, J., 1992. Impact of cloud longwave radiative surface forcing on interception loss from a coniferous forest canopy. Quarterly Journal of the Royal Meteorological Society 118, 1235-1239.

Loescher, H., Gholz, H., Jacobs, J., Oberbauer, S., 2005. Energy dynamics and modeled evapotranspiration from a wet tropical forest in Costa Rica. Journal of Hydrology 315, 274-294.
Loustau, D., Berbigier, P., Granier, A., 1992. Interception loss, throughfall and stemflow in a maritime pine stand. II. An application of Gash's analytical model of interception. Journal of Hydrology 138, 469-485.

Massman, W., 1983. The derivation and validation of a new model for the interception of rainfall by forest. Agricultural Meteorology 28, 261-286.

McKnight, T.L., Hess, D., 2000. Physical Geography: A Landscape Appreciation. Prentice Hall.

Merriam, R., 1960. A note on the interception loss equation. Journal of Geophysical Research 65, 3850-3851.

Monteith, J., 1965. Evaporation and environment. Symposia of the Society for Experimental Biology 19, 205-234.

Mulder, J., 1985. Simulating interception loss using standard meteorological data In: Hutchison, B., Hicks, B. (Eds.), The Forest-Atmosphere Interaction. Reidel Publishing Company, Dordrecht, pp. 77-196.

Murakami, S., 2006. A proposal for a new forest canopy interception mechanism: splash droplet evaporation. Journal of Hydrology 319, 72-82.

Murakami, S., 2007. Application of three canopy interception models to a young stand of Japanese cypress and interpretation in terms of interception mechanism. Journal of Hydrolgy 342, 305-319.

Navar, J., Bryan, R., 1994. Fitting the analytical model of rainfall interception of Gash to individual shrubs of semi-arid vegetation in northeastern Mexico. Agricultural and Forest Meteorology 68, 133-143.

Navar, J., Carlyle-Moses, D., Martinez, M.A., 1999a. Interception loss from the Tamaulipan matorral thornscrub of north-eastern Mexico: an application of the Gash analytical interception loss model. Journal of Arid Environments 41, 1-10.

Navar, J., Charles, F., Jurado, E., 1999b. Spatial variations of interception loss components by Tamaulipan thornscrub in northeastern Mexico. Forest Ecology and Management 124, 231-239.

Pearce, A., Gash, J., Stewart, J., 1980. Rainfall interception in a forest stand estimated from grassland meteorological data. Journal of Hydrology 46, 147-163.

Pearce, A., Rowe, L., 1981. Rainfall interception in a multi-storied, evergreen mixed forest: estimates using Gash's analytical model. Journal of Hydrology 49, 341353.

Penman, H., 1948. Evaporation from open water, bare soil and grass. Proceedings of the Royal Society of London 193, 120-145.

Pereira, F., Gash, J., David, J., Valente, F., 2009a. Evaporation of intercepted rainfall from isolated evergreen oak trees. Do the crowns behave as wet bulbs? Agricultural and Forest Meteorology 149, 667-679.

Pereira, F., Gash, J., David, J., David, T., Monteiro, P., Valente, F., 2009b. Modelling interception loss from evergreen oak Mediterranean savannas. Application of a tree-based modelling approach. Agricultural and Forest Meteorology 149, 680688.

Ploey, J.D., 1982. A stemflow equation for grasses and similar vegetation. Catena 9 , 139-152.

Price, A., Carlyle-Moses, D., 2003. Measurement and modelling of growing-season canopy water fluxes in a mature mixed deciduous forest stand, southern Ontario, Canada. Agricultural and Forest Meteorology 119, 69-85.

Pypker, T., Bond, B., Link, T., Marks d., D., Unsworth, M., 2005. The importance of canopy structure in controlling the interception loss of rainfall: examples from a young and an old-growth Douglas-fir forest. Agricultural and Forest Meteorology 130, 113-129.

Rao, A., 1987. Interception losses of rainfall from cashew trees. Journal of Hydrology 90, 293-301.

Rowe, L., 1983. Rainfall interception by an evergreen beech forest, Nelson, New Zealand. Journal of Hydrology 66, 143-158.

Rutter, A., 1967. Evaporation in forests. Endeavour 26, 39-43.

Rutter, A., Kershaw, K., Robins, P., Morton, A., 1971. A predictive model of rainfall interception in forest. I. Derivation of the model from observation in a plantation of Corsican pine. Agricultural Meteorology 9, 367-384.

Rutter, A., Morton, A., Robins, P., 1975. A predictive model of rainfall interception in forests. II. Generalization of the model and comparison with observations in some coniferous and hardwood stands. Journal of Applied Ecology 12, 367-380.

Schellekens, J., 2000. The interception and runoff generating processes in the Bisley catchment, Luquillo Experimental Forest, Puerto Rico. Physics and chemistry of the Earth part B-Hydrology oceans and atmosphere 25, 659-664.

Schellekens, J., Scatena, F., Bruijnzeel, L., Wickel, A., 1999. Modelling rainfall interception by a lowland tropical rainforest in northeastern PuertoRico. Journal of Hydrology 225, 168-184.

Sellers, P., Lockwood, J., 1981. A computer simulation of the effects of differing crop types on the water balance of small catchments over a long time periods. Quarterly Journal of the Royal Meteorological Society 107, 395-414.

Stewart, J., 1977. Evaporation from wet canopy of a pine forest. Water Resources Research 13, 915-921.

Sraj, M., Brilly, M., Mikoš, M., 2008. Rainfall interception by two decidous Mediterranean forests of contrasting stature in Slovenia. Agricultural and Forest Meteorology 148, 121-134.

Tallaksen, L., Schunselaar, S., van Veen, R., 1996. Comparative model estimates of interception loss in a coniferous forest stand. Nordic Hydrology 27 (3), 143-160.

Tani, M. Nik, A Yasuda, Y, Noguchi, S, Shamsuddin, S, Sahat, M., Takanashi, S. 2003. Long-term estimation of evapotranspiration from a tropical rain forest in Peninsular Malaysia. IAHS-AISH Publication 280, 267-274.

Valente, F., David, J., Gash, J., 1997. Modelling interception loss for two sparse eucalypt and pine forests in central Portugal using reformulated Rutter and Gash analytical models. Journal of Hydrology 190, 141-162.

van der Salm, C., Reinds, G., de Vries, W., 2007. Water balances in intensively monitored forest ecosystem in Europe. Environmental Pollution 148, 201-212. 
van Dijk, A., Bruijnzeel, L., 2001a. Modelling rainfall interception by vegetation of variable density using an adapted analytical model, part 1 . Model description. Journal of Hydrology 247, 230-238.

van Dijk, A., Bruijnzeel, L., 2001b. Modelling rainfall interception by vegetation of variable density using an adapted analytical model. Part 2. Model validation for a tropical upland mixed cropping system. Journal of Hydrology 247, 239262.

Wallace, J., McJannet, D., 2006. On interception modelling of a lowland coastal rainforest in northern Queensland, Australia. Journal of Hydrology 329, 477488.

Wallace, J., McJannet, D., 2008. Modelling interception in coastal and montane rainforests in northern Queensland, Australia. Journal of Hydrology 348, 480495.

Wang, D., Wang, G., Anagnostou, E., 2007. Evaluation of canopy interception schemes in land surface models. Journal of Hydrology 347, 308-318.

Ward, R., Robinson, M., 1990. Principles of Hydrology. McGraw-Hill Publishing Company, London. 365 pp.
Whelan, M., Anderson, J., 1996. Modelling spatial patterns of throughfall and interception loss in a Norway spruce (Picea abies) plantation at the plot scale. Journal of Hydrology 186, 335-354.

Whitehead, D., Kelliher, F., 1991. A canopy water balance model for a Pinus radiata stand before and after thinning. Agricultural and Forest Meteorology 55, 109126.

Xiao, Q., McPerson, E., Ustin, S., Grismer, M., 2000. A new approach to modeling tree rainfall interception. Journal of Geophysical Research 105, 173-188.

Zeng, N., Shuttleworth, J., Gash, J., 2000. Influence of temporal variability of rainfall on interception loss. Part 1. Point analysis. Journal of Hydrology 228, 228-241.

Zhang, G., Zeng, G., Jiang, Y., Huang, G., Li, J., Yao, J., Tan, W., Xiang, R., Zhang, X. 2006. Modelling and measurement of two-layer-canopy interception losses in a subtropical evergreen forest of central-south China. Hydrology and Earth System Sciences 10, 65-77.

Zinke, P., 1967. Forest interception studies in the United States. In: Sopper, W., Lull, H. (Eds.), International Symposium on Forest Hydrology. Pergamon, Oxford, pp. 37-161. 